\title{
Recessions and Recoveries in New Zealand's Post-Second World War Business Cycles
}

\author{
Viv B. Hall ${ }^{\mathrm{a} *}$ and C. John McDermott ${ }^{\mathrm{b}}$ \\ 23 October 2013 \\ ${ }^{a}$ School of Economics \& Finance, Victoria University of Wellington; \\ ${ }^{b}$ Reserve Bank of New Zealand, and School of Economics \& Finance, \\ Victoria University of Wellington.
}

\begin{abstract}
We compute classical real GDP business cycles and growth cycles, and contrast classical recessions with 'technical' recessions. Calling a technical recession after two successive quarters of negative growth can provide conditionally useful information, but can also signal beginning and end points for a recession that are somewhat different from those computed by our Bry and Boschan method. Expansion and contraction phases of classical real GDP and employment cycles have, on average, had an $89 \%$ association, but individual cycle circumstances should additionally be assessed. There is prima facie evidence that the severity of New Zealand's recessions has mattered for subsequent recovery paths, that severity of recessions has been more closely associated with their depth than duration, and that New Zealand's average pattern of recovery has differed from that for U.S. NBER cycles.
\end{abstract}

From our classical real GDP turning points, New Zealand's most recent recession commenced with the March 2008 quarter and ended with the June 2009 quarter. The duration of this six-quarter recession has been somewhat longer than the average recession of 4.3 quarters; but its 4.0 percentage depth has been considerably less than those for the 1951/52 and 1948 recessions, somewhat below that for the 1976/78 episode, and marginally less than the average depth of 4.1 per cent. In terms of overall severity, a measure which reflects both duration and depth, this recession has been New Zealand's fourth most severe. Its cumulated GDP loss of 11.5 per cent has been greater than the average loss of 10.4 per cent, but less severe than the losses for 1951/52 (37.2 per cent), 1948 (15.6 per cent) and 1976/78 (12.8 per cent).

The recovery path from New Zealand's most recent recession has differed from those of previous recoveries.

JEL Classification: E01, E24, E32

Keywords: Classical business cycles; growth cycles; employment cycles; recessions; economic recoveries; New Zealand

${ }^{*}$ Corresponding author. Email: viv.hall@ vuw.ac.nz 


\section{Recessions and Recoveries in New Zealand's Post-Second World War Business Cycles}

\section{Introduction}

In the wake of the global financial crisis, New Zealand has recorded a range of positive and negative real GDP growth rates, and markedly variable employment growth rates.

Against this background, we first present updated classical business cycle turning points and properties for the Hall and McDermott (2011) quarterly real GDP series through to 2012q3. These results update those published in Hall and McDermott (2009). We then establish the number of two-or-more-quarter negative growth rate (or 'technical') recessions recorded for New Zealand's post-Second World War economy, and offer a set of growth cycle turning points similar to those published by the MIAESR (2013). This enables us to assess the extent to which New Zealand's classical and growth cycle contraction phases have been consistent with its technical recessions.

Next, we provide a set of classical employment cycle peaks and troughs from a linked quarterly Chapple (1994)-RBNZ-SNZ total employment series dating from 1956q1. This enables us to assess the degree of association between output and employment cycles.

Our assessments are considered in the context of the procedures used by the NBER's Business Cycle Dating Committee (NBER, 2010), who state that most but not all of their identified U.S. recessions consist of two or more quarters of declining real GDP, and that the committee neither relies on a simple rule of thumb such as two successive quarters of negative growth nor on real GDP alone.

The classical business cycle and employment cycle turning points reflect Bry-Boschan (1971) dating, and the growth cycle turning points reflect HP 1600 detrending and Bry-Boschan-assisted dating. The results for degree of association are obtained from the concordance-based methodology of Harding and Pagan $(2002,2006)$, as illustrated for New Zealand regional cycles in Hall and McDermott (2007).

From the above results, we can then address questions such as the following: (1) how often in New Zealand's post-Second World War sample period would calling a technical recession have provided potentially misleading signals to decision makers?; (2) would the publishing of growth cycle peaks and troughs have added greater confusion or further enlightenment?; (3) have New Zealand's classical real GDP and employment cycles been closely associated, and should employment peaks and troughs additionally be taken into account when calling the beginning and end of a recession?; and (4) to what extent have the severities of New Zealand's recessions and strengths of recoveries differed over time, and does the severity of preceding contractions/recessions matter for subsequent economic recovery? Also, (5), how different has the recovery path from New Zealand's most recent recession been?

With respect to these questions, literature on recoveries from recessions has been relatively modest,e.g. Wynne and Blake (1992), Sichel (1994), Balke and Wynne (1995)), but in the 
context of the recent global financial crisis there has been some resurgence (e.g. IMF (2009), Reinhart and Rogoff (2009), Hall (2010, 2011), Claessens et al., (2011, 2012), Mussa (2010), Bordo and Haubrich (2012), and Dominguez and Shapiro (2013)) .

The paper is structured as follows: Section 1 has introduced. Section 2 provides evidence on the three sets of real GDP business cycles, and assesses the credibility of calling two-or-more negative- quarter recessions. In section 3, classical employment cycle turning points and properties are presented and their degree of association with classical output cycles is assessed. Section 4 presents evidence on recession, recovery and expansion phases, along with evidence from two recent New Zealand business cycle recoveries. Section 5 concludes. The Appendix provides the Hall-McDermott (2011) quarterly real GDP data updated to 2012q3, and the linked quarterly Chapple (1994)-RBNZ-SNZ total employment series dating from 1956q1.

\section{New Zealand's real GDP business cycles, and the credibility of calling 'technical' recessions}

In 1946, Arthur Burns and Wesley Mitchell (1946, p 3) of the U.S. National Bureau of Economic Research (NBER) advanced their now widely-recognised definition of a business cycle, namely that "Business cycles are a type of fluctuation found in the aggregate activity of nations; ... a cycle consists of expansions occurring at about the same time in many economic activities, followed by similarly general ... contractions ...". This definition recognises that every business cycle will have a peak, a trough, an expansion phase between its trough and peak, and a contraction phase between its peak and trough.

The NBER (2010) also refers to a recession as a period between a peak and a trough, though in a more detailed sense consider a recession as a "... significant decline in economic activity spread across the economy, lasting more than a few months, normally visible in production, employment, real income, and other indicators." They further state that most but not all of their identified U.S. recessions consist of two or more quarters of declining real GDP, and that the committee relies neither on a simple rule of thumb such as two successive quarters of negative growth nor on real GDP alone.

There is no universally accepted way of operationalising the measurement of these business cycle characteristics, though two widely utilised types of cycle are the classical cycle and the growth cycle. Empirical results for our updated New Zealand real GDP series are considered for each of these two broad categories of cycle, along with a set of technical recessions called from two or more quarters of negative real GDP growth.

\subsection{The Classical business cycles and their properties}

A Classical cycle is concerned with movements in the levels (or log levels) of an aggregate economic series such as real GDP, and since 1971 economists have successfully used computer algorithms to automate the NBER method of dating turning points. It is also the case that for nearly 20 years in New Zealand, either BB or BBQ quarterly adaptations of the simple, transparent, and readily replicated Bry and Boschan (1971) methodology have been used successfully to assist in dating quarterly classical turning points in real GDP, aggregate economic 
activity and regional economic activity series. Details of the BB algorithm used to derive the classical turning points presented in this paper can be found in those previous applications (Kim, Buckle and Hall, 1995; Hall and McDermott, 2007; and Hall and McDermott, 2009) ${ }^{\mathrm{i}}$.

We identify eight peak-to-peak classical real GDP cycles for New Zealand's post-Second World War period (Table 1) ${ }^{\mathrm{ii}}$. These cycles have an average expansion phase of almost 6.5 years, and an average contraction phase of just over one year. The average expansion phase has therefore been considerably longer than the average contraction phase, though individual cycles should obviously be considered in the context of New Zealand's business cycles and phases having continued to display considerable variation around averages, especially over expansion phases (Figure 1, bottom panel). The average expansion phase duration of 25.9 quarters has a standard deviation of 17.1 quarters, and the average contraction phase of 4.3 quarters has a standard deviation of 1.7 quarters.

This considerable individual cycle diversity is not dissimilar to that experienced by Australia. For example, taking New Zealand's cycles for the 1960-2011 period of Australia's monthly classical cycles (MIAESR, 2013), and bearing in mind that the Australian figures exclude the still incomplete expansion phase of their current cycle, the average cycles, expansion and contraction durations have been 6.5, 5 and 1.5 years for Australia, and 8.1, 7.1 and 1 years for New Zealand. Their standard deviations are also not dissimilar: 4.2, 4.3 and 0.3 years for Australia and 4.3, 4.2 and 0.4 years for New Zealand.

From the classical real GDP turning points, we confirm that New Zealand's most recent recession commenced with the March 2008 quarter and ended with the June 2009 quarter. The duration of this six-quarter recession has been somewhat longer than the average post-Second World War recession of 4.3 quarters; but its 4.0 percentage depth has been considerably less than those for the 1951/52 and 1948 recessions, somewhat below that for the 1976/78 episode, and marginally less than the average depth of 4.1 per cent.

But what of the overall severity of the eight recessions? The Harding and Pagan (2002) and Pagan $(2005$, p11) measure of cumulated gain or loss can be used to reflect both the combined duration and depth (amplitude) of a recession, and by this measure, New Zealand's most recent recession has been its fourth most severe. Its cumulated GDP loss of 11.5 per cent has been greater than the average loss of 10.4 per cent, but less severe than the losses for 1951/52 (37.2 per cent), 1948 (15.6 per cent) and 1976/78 (12.8 per cent). (Table 2)

\subsection{How many technical recessions?}

When we compute turning points from the easy-to-follow, frequently-used practice of calling a recession immediately after two successive quarters of negative real GDP growth have been published, we obtain 11 completed peak-to-peak cycles and 12 contractionary phases. This compares with the eight classical cycles and nine contractionary phases computed from the BB method (Table 3). The additional three short technical recessions of two, four and two quarters would have been for $1975 q 3$ to $1975 q 4,1989 q 3$ to $1990 q 2$, and most recently for the $2010 q 3$ to $2010 \mathrm{q} 4$ period $^{\mathrm{iii}}$. Also, the troughs of the 1951/52 and 1988 recessions would have been called two quarters earlier at 1951q4 and 1988q2, and the beginning of the 1967 recession would have 
been called two quarters later at 1967q3.

On this evidence, do two or more quarters of negative real GDP growth always constitute a recession? The short answer is 'not always', though this should be further seen in the context of this procedure correctly calling six of the nine recessions, and the beginning quarter for eight of the nine recessions. The NBER (2010) provide illustrations as to why their Dating Committee will not accept unconditionally the two-quarter convention, including because they require evidence of a 'significant decline in economic activity spread across the economy', and wish to consider more than just real GDP series and more than just 'product-side' GDP estimates.

Hence, although we show that the commonly-used practice of calling a technical recession can provide conditionally useful evidence, this procedure can also on occasions signal somewhat different beginning and end points for a recession. For example, the procedure matched exactly six of the nine Classical business cycle contraction phases identified by the Bry-Boschan method, but it also called three additional recessions and called differently by two quarters the timing of a beginning or end point for three of the nine recessions. This suggests that a signal provided by this procedure should not be used on its own for the formal calling of a recession.

\section{What about growth cycles and growth cycle recessions?}

A growth cycle reflects fluctuations in aggregate economic activity relative to an appropriate trend in the series. There are a considerable number of ways of 'detrending' individual series, and hence of getting the corresponding 'deviations-from-trend' growth cycles.

Here, we first de-trend our real GDP series, utilising the well-known HP 1600 procedure previously used successfully for New Zealand series reported in Kim, Buckle and Hall (1994, 1995), and Hall, Kim and Buckle (1998); we then use the BB algorithm to identify turning points in the de-trended series (Tables 3, 4; Figure 1, top panel).

Perhaps not surprisingly, given that movements in New Zealand's real GDP series are relatively volatile by international standards, the use of this growth cycle methodology would have led to calling 15 completed peak-to-peak cycles compared with only eight classical cycles, and would have recorded 16 potential post-Second World War recession periods with an average duration of 1.7 years and a standard deviation of 8.4 months. The average expansion phase is commensurately very much shorter, at 2.3 years relative to 6.5 years for the average classical cycle.

This calling of an excessive number of much shorter cycles, significantly shorter expansion phases, and somewhat longer contraction phases suggests that the formal establishment of a set of growth cycle turning points and 'growth recessions' would not have been helpful for economic decision makers.

This is not to say, however, that the computation of sample-average growth cycle properties for the purposes of establishing key business cycle facts, to assist the calibration of modern DSGE and other macro models, will not remain a valuable exercise. 


\section{New Zealand's employment cycles}

Although the NBER Business Cycle Dating Committee does not have a fixed definition of 'economic activity', it considers 'economy-wide employment' as a key broad measure when finalising its business cycle turning points. This seems not least when its real GDP and real gross domestic income (GDI) measures are not providing sufficiently clear signals.

We therefore assess whether a measure of New Zealand's total employment might provide insights additional to those provided by our real GDP series. To do this we had to search for a credible quarterly total employment series which could extend back as least as far as the 1950s.

Claus (2011) has recently incorporated labour market indicators, so as to assess seven leading indicators of New Zealand employment, but with the relatively short sample period 1990q1 to 2005q3. Statistics New Zealand's (SNZ) Household Labour Force Survey (HLFS) series extend further back but only as far as 1986q1, and are therefore also too short on their own for our purposes. Fortunately, however, Simon Chapple (1994) has published a number of HLFS-consistent series back to $1956 \mathrm{q} 1$, and from this and the corresponding Chapple total employment observations available in electronic form from the RBNZ's website, we are able to use what we refer to as a linked Household Labour Force Survey (HLFS)-consistent Chapple-RBNZ-SNZ total employment series to compute classical employment cycle turning points and associated properties ${ }^{\mathrm{iv}}$.

The use of this sample period has the advantage of extending quarterly total employment observations sufficiently far back so as to cover six of our eight completed Classical real GDP cycles, i.e. they exclude only the relatively unusual 1948 and 1951/52 contraction phases ${ }^{v}$.

\subsection{The Classical employment cycles}

If we take the period to the end of 2011, the numbers of peak-to-peak employment cycles and associated expansion and contraction phases are the same as those for our classical GDP cycles, i.e. six cycles, six expansion phases and seven contraction phases (Table 5; Figure 2, bottom panel). Their average durations are also very similar.

However, more recently, employment has peaked at 2012q1, ahead of the yet-to-be determined next real GDP peak, and this has created a seventh employment expansion phase, equal to the number of completed contraction phases. In this context, it is noticeable that while the average durations for employment and real GDP cycles, expansion and contraction phases have remained relatively similar, the average standard deviations for employment cycles and phases have been considerably higher than for their real GDP counterparts.

Moreover, visual inspection of the recessions shaded in the two panels of Figure 2 reveals that the average properties fail to highlight different timings and durations for a number of the individual cycles. For example, employment troughs lag output troughs for six of our seven cycle troughs, but employment peaks have variously led, lagged or been contemporaneous with output peaks. It is also worth noting that employment peaks have led real GDP peaks on three occasions, 
the most recent being for the employment peak of $2012 \mathrm{q} 1$.

So, can one get a summary guiding rule as to the extent to which employment peaks and troughs might have led, lagged or been contemporaneous with those for real GDP?

\subsection{How associated are output and employment cycles?}

We have previously used the simple non-parametric concordance statistic of Harding and Pagan (2002, 2006) to establish the statistical significance of associations between New Zealand's aggregate and regional economic activity cycles (Hall and McDermott, 2007). We again follow this methodology.

A concordance statistic describes the proportion of time during which two series for which one has cyclically dated turning points, are in the same phase of expansion or contraction. In our case, we assign a value of one when both the real GDP series $\left(x_{i}\right)$ and the employment series $\left(x_{j}\right)$ are expanding or contracting, and award a value of zero otherwise. Then, following Harding and Pagan (2002), we let $S_{i, t}$ be a binary random variable with value one when the classical cycle for the real GDP series is in an expansion phase and zero when it is in a contraction phase; similarly, $S_{j, t}$ is the binary random variable for the employment series. The index of concordance for these two series then becomes

$$
C_{i j}=T^{-1}\left\{\sum_{t=1}^{T}\left(S_{i, t} \cdot S_{j, t}\right)+\sum_{t=1}^{T}\left(1-S_{i, t}\right)\left(1-S_{j, t}\right)\right\}
$$

where $T$ is the sample size, and $C_{i j}$ is the measure of the proportion of time the two series are in the same phase. By way of interpretation, this means that the real GDP series would be in the same expanding or contracting phase exactly pro-cyclically if $C_{i j}$ had value one, and exactly counter-cyclical if $C_{i j}$ were to have value zero.

We are, however, interested not only in the magnitude of the concordance statistic but also in its statistical significance. To obtain the corresponding tests for significance, we again follow a procedure suggested by Harding and Pagan (2002), and as outlined more fully in Hall and McDermott (2007, section 2.2). The procedure involves using a GMM estimator, with moment condition

$$
E\left(\left(S_{i, t}-\bar{S}_{i, t}\right)\left(S_{j, t}-\bar{S}_{j, t}\right)-a\right)=0
$$

where $\bar{S}_{i, t}$ is the mean of the real GDP time series $S_{i, t}$, and the test of significance is whether $a=0$.

From our concordance statistic measures, we find that our classical employment cycle series have been in expansion or contraction phase procyclically with the real GDP series 89 per cent of the time, and the strongest statistical significance occurs where employment cycle turning points lag those of output cycles by one quarter (Table 6). However, it should also be borne in mind that contemporaneous and two quarter lag specifications both have statistically significant associations of 87 per cent. 


\subsection{Should employment peaks and troughs additionally be taken into account when calling the beginning and end of a recession?}

The empirical evidence presented immediately above suggests that while the expansion and contraction phases of real GDP and employment cycles have, on average, been closely associated, it has also not been the case for every individual cycle that the expansion and contraction phases for employment have lagged real GDP phases by one quarter.

This suggests that if one is additionally considering movements in total employment for the purposes of calling turning points for a recession, then as a minimum the circumstances particular to that cycle should also be assessed. But it should also be recognised that the above results are preliminary in nature, and there could be benefit from further investigation of the extent to which employment cycle information should or should not be taken into account formally when calling beginning and end periods for New Zealand's recession periods ${ }^{\mathrm{vi}}$.

\section{Recessions, recoveries and expansions}

In the context of what Robert Hall (2011, pp 431-432) has recently termed the "Great [U.S.] Slump"vii that commenced in late 2007, and what some others have referred to as the "Great Recession", there has been a resurgence of interest in recessions, recoveries and expansion phases, e.g. IMF (2009), Reinhart and Rogoff (2009), Hall (2010, 2011), Claessens et al., (2011, 2012), Mussa (2010), Bordo and Haubrich ( 2012), and Dominguez and Shapiro (2013).

In much earlier work, Wynne and Balke (1992) addressed the question of whether deep recessions in the U.S. over the period 1884-1990 had been followed by strong recoveries, and found ( $p$ 187) that the relationship between the size of the peak-to-peak decline and growth in the twelve-month period following the trough is statistically significant ${ }^{\text {viii }}$.

In other earlier work, using U.S. real data for the period 1950q1 to 1992q4, Sichel (1994) investigated whether recessions have typically been followed by high-growth recoveries back to pre-recession levels. He concluded in the affirmative (p 276).

Against this background, the results reported in sections 4.1 and 4.2 provide a preliminary perspective on the extent to which there may have been associations between the length, depth, and severity of New Zealand's post-Second World War recessions, and recovery and expansion phases. We then illustrate in section 4.3, as have Sichel (1994), Balke and Wynne (1995), Hall (2010, 2011), and Mussa (2011) for the U.S., and Boivin (2011) for Canada, the behaviour of key GDP expenditure components for New Zealand's post-1991q2 and post-2009q2 recovery phases.

\subsection{To what extent have the depths and severities of New Zealand's recessions and strengths of recoveries differed over time?}

Depths of contraction phases/recessions, and strengths of recovery and expansion phases can be illustrated by amplitude per quarter or the equivalent annualised measures (Table 7). 
The average annualised amplitude (or depth) for New Zealand's nine post-Second World War recessions has been -3.8 per cent, though if the two deepest recessions from 1948q1 and 1991q1 are excluded the average is reduced to -3.0 per cent. The average is reduced further to -2.5 per cent if the third most severe recession from 1951q1 is excluded, a figure which is closer to but still greater than the average of -2.2 per cent found by Claessens et al (2012, Table 1) for 21 "advanced" OECD countries for the period 1960q1 to $2010 q 4$.

New Zealand's most recent recession of six quarters has been longer than the average of 4.3 quarters, its depth of -3.90 per cent has been a shade shallower than the average of -3.95 per cent, and its annualised depth of -2.6 per cent ranks fifth, considerably less than the average of -3.8 per cent, and far less deep than the -7.7 per cent and -6.1 per cent figures for the recessions from 1948q1 and from 1991q1. The two shallowest recessions of 1988 and 1998 registered -1.3 and -1.7 per cent respectively (Table 7 , top panel).

With respect to recovery phases relative to expansion phases, it is first important to make clear the definition used for "recovery". Researchers have variously used the number of quarters from trough back to previous peak (Claessens et al., 2012; Sichel, 1994), and fixed periods such as the initial four quarters (Wynne and Balke, 1992) or initial six quarters (Mussa, 2010). The recovery phases we present are from trough back to previous peak (Table $7,3^{\text {rd }}$ panel).

Not surprisingly, the average duration of New Zealand's nine completed recovery phases, at 6.6 quarters, is considerably below the average of 25.9 quarters for completed expansion phases. The average recovery phase is reduced to 5.8 quarters if the exceptionally long 13-quarter recovery from 1978q1 is excluded, but this average is still longer than Claessens et al's (2012, Table 1) advanced OECD country average of 4.3 quarters. However, New Zealand's average recovery amplitude has been 5.4 per cent relative to the 21-country OECD average of 3.1 per cent, and so the annualised average strength of New Zealand's recoveries of 4.0 per cent would also have been greater than that for the 21-country OECD average.

The durations of New Zealand's individual recovery periods have varied from a very short two quarters to a very lengthy 13 quarters. The strength of individual recoveries has also varied considerably, from a low annualised rate of 1.2 per cent after the $1988 \mathrm{q} 4$ trough and the modest rate of 2 per cent after the 2009q2, 1991q2 and 1978q1 troughs, to an exceptionally strong annualised rate of 10.8 per cent from $1948 \mathrm{q} 4$ and a robust 7.0 per cent post-1983q1.

\subsection{Does the depth of preceding contractions/recessions matter for subsequent economic recovery?}

Once the trough of a particular business cycle becomes sufficiently clear, the attention of many economic decision makers focuses on the strength of the recovery and the sustainability of the expansion path. We assess aspects of this issue in the context of measures for New Zealand's quarters of recovery to previous peaks, its average annualised growth rates during recession having declined within the range 1.3 to 7.7 per cent (Table 8), and the findings of Sichel (1994) that U.S. recessions have typically been followed by high-growth recoveries. Another way of addressing the latter issue is to ask whether a country might have had a stronger, more sustained 
recovery, if it had had a (short) deep recession rather than a prolonged shallow recession.

During New Zealand's nine post-Second World War recessions, the average annualised contraction in real GDP has been 3.8 per cent, followed by steadily increasing real GDP growth over the next two years, from 3.0 per cent during quarters 1 and 2 up to 5.5 per cent during quarters 7 and 8. This two-year recovery pattern is the opposite of that found by Sichel (1994, Figure 1) for average U.S. NBER contractions of around 2.1 per cent from 1950q1 to 1992q4. This opposite recovery pattern is confirmed when the data for Sichel's sample period is updated to be the same as for our New Zealand sample period of $1947 \mathrm{q} 2$ to $2012 \mathrm{q} 3$. (Figure $3,1^{\text {st }}$ and $3^{\text {rd }}$ panels $)^{\mathrm{ix}}$.

A somewhat modified pattern is evident for New Zealand when its four deepest recessions are excluded from the averaging. (Figure 3, $2^{\text {nd }}$ panel; Table 8). Then the average annualised contraction for the five shallower recessions (varying from -1.3 to -2.6 per cent) is also 2.1 per cent, and the associated average recovery path becomes both more varied and more muted for the initial three years in particular. Overall, though, the finding of an opposite recovery pattern is not overturned.

Hence, though no formal tests have been conducted, there is prima facie evidence that the depth of the preceding recession has mattered for the subsequent recovery path. More particularly, it is possible that shallower recession periods could well not be followed by immediately high-growth recoveries, especially if recovery from the business cycle trough were then disturbed by adverse supply-side and/or external shocks. Also, whether the four deepest New Zealand recessions are included in or excluded from the average, the average pattern of recovery has been in direct contrast to the average experience of an immediately strong and subsequently declining recovery rates found for 1950 to 1992 and 1947 to 2012 U.S. NBER cycles.

It is well known that no two individual business cycles are the same in all respects, but it is also the case that some cycles may have certain features in common. To illustrate this, we found it informative to examine the recovery and expansion paths from New Zealand's 1991 two-quarter recession and its most recent 2008/09 six-quarter recession. In a very broad sense, one can say that the 1991 recession was associated with demand-side international (especially U.S. and Australian) contraction phases and contractionary New Zealand monetary and fiscal policies (Reddell and Sleeman, 2008), and a recovery path interrupted in the September 1992 quarter by electricity-generation restrictions. The 2008/09 recession has similarly been associated with global (financial crisis) activity contractions (Australia excepted) and then had its nascent recovery set back a considerable number of quarters by damage and disruption from the September 2010, February 2011, June 2011 and December 2011 Canterbury earthquakes.

These economic events resulted in a severe annualised decline in real GDP of 6.1 per cent during the 1991 recession, followed by an initially strong 1-2 quarter recovery rate of 2.0 per cent, subdued rates of 0.7 and 1.0 per cent during quarters 3 to 6 , and the return to a powerful 7.8 per cent rate during quarters seven and eight. There was then good growth of between 5.5 and 3.6 per cent during years three through to six of the 24-quarter expansion phase through to 1997q2, when New Zealand's growth rate was affected by the Asian financial crisis (Table 8). 
New Zealand's recovery from the 2008/09 recession began particularly strongly with a 4.4 per cent rate during the $1^{\text {st }}$ two quarters. The recovery lost some momentum during the next two quarters (1.7 per cent), before recording an average negative growth rate ( -1.4 per cent) for the following six months during which the September 2010 and February 2011 Canterbury earthquakes occurred. Growth momentum was then regained during quarters seven and eight (2.6 per cent) and during the third year of recovery ( 2.5 per cent $)$.

The current recovery path remains incomplete, though the production-based real GDP peak of $\$ 35,400 \mathrm{~m}$ (1995/96 prices) in the December 2007 quarter was regained in the September 2011 quarter $(\$ 35,574 \mathrm{~m})$. (Table 8 , Note $\dagger \dagger)$. This recovery-to-previous-peak of nine quarters is the second slowest for New Zealand's post-Second World War economy, surpassed only by the 13 quarters taken from the 1978q1 trough, but not materially slower than for the eight quarters taken from the 1988q4 and 1952q2 troughs and the seven quarters from the 1991q2 trough. (Table 7, panel 3).

So, to what extent might the considerably interrupted recovery from the 2008/09 recession continue to regain momentum and eventually produce an expansion phase as sustained as that from 1991q2 to 1997q2, and if so what would movements in GDP expenditure components have to be, to be consistent with achieving this?

\subsection{Severity of recessions and strength of recoveries, for New Zealand's real GDP expenditure components}

Here, we provide a visual perspective on movements in key real GDP expenditure components which underpin the current recovery phase, relative to movements of the same components over the lengthy post-June 1991 recovery (Figure 4).

The cumulated movements in the recoveries of aggregate real GDP expenditure from their post-1990q4 and post-2007q4 business cycle peaks through to their previous peaks had, by the end of 9 quarters, been broadly similar (Figure $4,1^{\text {st }}$ panel). Then came the immediate effects in 2010q3, 2010q4 and 2011q1 of the 4 September 2010 and 22 February 2011 Canterbury earthquakes. These interrupted what had promised to be a reasonably steady recovery path. Recovery has since continued at somewhat variable rates, though 2012q3 real GDP is still well below what could have been the case had a 1990q4 to $1995 \mathrm{q} 3$-type path eventuated. (Figure $4,1^{\text {st }}$ panel).

But how have the paths of the major components of real GDP expenditure fared for the two recoveries? Not surprisingly, their paths have been somewhat different. The 1990s displayed relatively modest contributions from both net exports and the combined private investment and consumer durables components over the first 11 quarters; this is in contrast to the initially strong and then modest boost from net exports during the current cycle, offset by the prolonged and particularly strong negative contribution from investment and durables (Figure $4,2^{\text {nd }}$ panel). This combined private investment expenditure and durables component had still not regained its 2007q4 level by 2012 q3.

The key demand-side drivers which sustained the 1990s expansion phase were the combined 
private investment and consumption durables component, and the nondurables consumption component (Figure $4,3^{\text {rd }}$ panel). It has been made clear immediately above that the former has made no net positive contribution during this recovery, and although consumer nondurables regained its previous peak more quickly during this recovery (nine quarters versus 14 quarters), overall its recovery has proceeded at a much more modest rate than during the 1990s. (Figure 4, $3^{\text {rd }}$ and $4^{\text {th }}$ panels). It is also clear from the evidence for both recoveries that components such as inventories and net exports cannot be relied on to sustain an expansion, unless substantial and sustained increases in the production of export goods and services can be achieved.

Consumer durables had still not recovered particularly strongly by quarter 13 for either of the two cycles, but by the end of 19 quarters had become equivalently sustaining for the growth process (Figure $4,5^{\text {th }}$ and $6^{\text {th }}$ panels). But what of the relatively different movements over the two recoveries for the general government and private (i.e. all sectors) investment and durables component? During the 1990 s recession, the latter declined for only three quarters by a cumulated $\$ 921$ million, and its sustained recovery began after seven quarters (Figure $4,5^{\text {th }}$ panel). However, during the most recent recession and recovery, first there was a contraction phase which lasted for eight quarters and in real terms cumulated to more than negative \$2300 million. This was followed by an initially promising and then twice-interrupted recovery phase, with a cumulated contraction by $2012 q 3$ of over $\$ 700$ million (Figure $4,6^{\text {th }}$ panel). Up until 2010q3, general government investment had played a modestly supportive role relative to its role during the 1990s, but consumer durables had been somewhat more subdued as had non-residential investment. Residential construction had also been more subdued, but the key under-contributor both up until 201q3 and subsequently has been "other" investment (primarily transport investment, and plant and equipment investment). By way of contrast, this other investment component had provided a cumulated $\$ 825 \mathrm{~m}$ boost by the end of quarter 19 during the 1990s recovery, considerably better than the cumulated negative $\$ 780 \mathrm{~m}$ contribution during the current recovery's equivalent 19 quarters (Figure $4,5^{\text {th }}$ and $6^{\text {th }}$ panels).

Hence, sustained increases in investment in "other" investment, but also in consumer durables and in consumer non-durables, ideally assisted by greater export volumes, will be necessary if the 1990s recovery and expansion phase is to be eventually emulated and then surpassed.

\section{Conclusion}

We provide an updated quarterly real GDP series for post-Second World War New Zealand. From this series, we present classical and growth cycle turning points, and a set of technical recession periods triggered by two or more successive quarters of negative growth. An associated set of classical employment cycles have also been developed.

From the classical real GDP turning points, we confirm that New Zealand's most recent recession commenced with the March 2008 quarter and ended with the June 2009 quarter. The duration of this six-quarter recession has been somewhat longer than the average post-Second World War contraction phase of 4.3 quarters, but its 4.0 percentage depth has been considerably less than those for the 1951/52 and 1948 recessions, somewhat below that for the 1976/78 episode, and marginally less than the average depth of 4.1 per cent. In terms of its overall severity, a measure which reflects both duration and depth, the recession has been New 
Zealand's fourth most severe. Its cumulated GDP loss of 11.5 per cent has been greater than the average loss of 10.4 per cent, but less severe than the losses for 1951/52 (37.2 per cent), 1948 (15.6 per cent) and 1976/78 (12.8 per cent).

We show that the commonly-used practice of calling a technical recession following the publication of two successive quarters of negative real GDP growth can provide conditionally useful evidence, but this procedure can on occasions also provide somewhat different signals as to a recession's beginning and end points. For example, the procedure matched exactly six of the nine classical business cycle recessions identified by the Bry-Boschan method, but it also called three additional recessions and called differently by two quarters the timing of a beginning point or end point for three of the nine recessions. This suggests that the evidence provided by this procedure should not be used on its own for formally calling the beginning and end of a recession.

Movements in New Zealand's real GDP series are relatively volatile by international standards. It's therefore not surprising that the use of growth cycle methodology would have led to calling 16 contraction phases or "growth recessions" rather than nine classical cycle recessions during the post-Second World War period. Publishing individual growth cycle recessions would therefore almost certainly have led to more confusion than clarity for economic decision makers.

Utilising our linked quarterly employment series from 1956q1 to establish classical employment cycles, we find that for the period to the end of 2011, the numbers of peak-to-peak cycles and associated expansion and contraction phases are the same as those for our classical GDP cycles. Further, their average durations were remarkably similar. However more recently, employment has peaked at 2012q1, ahead of the yet-to-be determined next real GDP peak, and this has created a seventh employment expansion phase, equal to the number of completed contraction phases. In this context, the average standard deviations for employment cycles and phases have been considerably higher than for their real GDP counterparts.

It should also be noted that the average properties fail to highlight different timings and durations for a number of the individual employment cycles. For example, employment troughs lag output troughs for six of our seven cycle troughs, but employment peaks have led real GDP peaks on three occasions, the most recent being for the employment peak of $2012 \mathrm{q} 2$.

From Concordance statistic measures, while the expansions and contraction phases of classical real GDP and employment cycles have, on average, been associated 89 per cent of the time, it has also not been the case that for every individual cycle that employment expansion and contraction phases have lagged real GDP phases by one quarter. This suggests that if one is additionally considering movements in total employment for the purposes of calling turning points for a recession, then as a minimum the circumstances particular to that cycle should also be assessed.

We have established statistics for the recovery-to-previous-peak phases of each New Zealand business cycle. The durations of these recovery periods have varied from a very short two quarters to a very lengthy 13 quarters, with an average of 6.6 quarters. The strength of the recoveries has also varied considerably, from a low annualised growth rate of 1.2 per cent after 
the $1988 \mathrm{q} 4$ trough to an exceptionally strong annualised rate of 10.8 per cent from $1948 \mathrm{q} 4$ and a robust 7.0 per cent post-1983q1.

Though no formal tests have been conducted, there is prima facie evidence that the severity of the preceding recession has mattered for the subsequent recovery path. For example, when all recessions are taken into account, the average growth rate has steadily increased over the following two years, from an annualised 3.0 per cent during the immediately following two quarters through to 5.5 per cent during quarters seven and eight. However, when recoveries following the four deepest recessions are excluded, the average recovery path has been both more varied and more muted for the following three years in particular. In both cases, though, the average pattern of recovery has been in direct contrast to the experience of on-average rapid initial expansion and subsequent declining recovery rates found for U.S. NBER cycles over the 1950 to 1992 and 1947 to 2012 periods.

Finally, we provide a visual perspective on movements in the key real GDP expenditure components which underpin the current recovery phase, relative to movements of the same components over the lengthy post-June 1991 recovery phase.

\section{Acknowledgements}

We thank Brian Easton for his very helpful insights on key data periods, and for supplying his Haywood and Campbell diffusion index data during our construction of the preferred Hall and McDermott (2011) data series.

\section{References}

Balke, Nathan S. and Mark A. Wynne (1995), "Recessions and recoveries in real business cycle models", Economic Enquiry, 33, 640-663.

Boivin, Jean (2011), "The "Great" Recession in Canada: Perception vs. Reality", Remarks to Montréal CFA society, Bank of Canada, 28 March.

Bordo, Michael D. and Joseph G. Haubrich (2012), "Deep recessions, fast recoveries, and financial crises: Evidence from the American record", NBER Working Paper 18194, June; http://www.nber.org/papers/w18194.

Bry, G. and C. Boschan (1971), Cyclical analysis of time series: Selected procedures and a computer program, Columbia University Press.

Burns, A.F. and W.C. Mitchell (1946), Measuring Business Cycles, New York: NBER.

Chapple, Simon (1994), "HLFS - Consistent labour market data", NZIER Working Paper 94/16.

Claessens, Stijn, Ayhan Kose and Marco E. Terrones (2011), "Financial Cycles: What? How? When?", IMF Working Paper 11/76.

Claessens, Stijn, Ayhan Kose and Marco E. Terrones (2012), "How do business and financial cycles interact?", Journal of International Economics, 87(1), May, 178-190.

Claus, Edda (2011), "Seven leading indexes of New Zealand employment", The Economic Record, 87(276), 76-89.

Dominguez, Kathryn M. E. and Matthew D. Shapiro (2013), "Forecasting the Recovery from the Great Recession: Is This Time Different?", American Economic Review: Papers \& Proceedings, 103(3), 147-152. 
Easton, Brian (1997), In Stormy Seas: The Post-War New Zealand Economy, University of Otago Press, Dunedin.

Easton, Brian (2009), "It's the same this time? Cycles and depressions in New Zealand history", Policy Quarterly, 5(1), 17-23.

Hall, Robert E. (2010), "Why does the economy fall to pieces after a financial crisis?", Journal of Economic Perspectives, 24(4), 3-20.

Hall, Robert E. (2011), “The long slump", American Economic Review, 101(2), 431-469.

Hall, Viv B, Kunhong Kim and Robert A. Buckle (1998), "Pacific Rim business cycle analysis: Synchronisation and volatility", New Zealand Economic Papers, 32(2), 129-159.

Hall, Viv B. and C. John McDermott (2007), "Regional Business Cycles in New Zealand. Do they exist? What might drive them?”, Papers in Regional Science, 86(2), June 2007, 167-191.

Hall, Viv B. and C. John McDermott (2009), "The New Zealand Business Cycle”, Econometric Theory, 25(4), August 2009, 1050-1069.

Hall, Viv B. and C. John McDermott (2011), "A quarterly post-Second World War real GDP series for New Zealand", New Zealand Economic Papers, 45(3), December 2011, 273-298.

Harding, Don and Adrian Pagan (2002), "Dissecting the Cycle: A Methodological Investigation”, Journal of Monetary Economics, 49, 365-381.

Harding, Don and Adrian Pagan (2006), "Synchronisation of cycles", Journal of Econometrics, 132, 59-79.

Haywood, E. and C. Campbell (1976), The New Zealand economy: Measurement of economic fluctuations and indicators of economic activity, 1947-74, Reserve Bank of New Zealand Research Paper, No. 19.

International Monetary Fund (2009), "From recession to recovery: How soon and how strong", World Economic Outlook, April, ch 3, 103-138.

Kim, Kunhong, Robert A. Buckle and Viv B. Hall (1994), "Key features of New Zealand business cycles", The Economic Record, 70, 56-73.

Kim, Kunhong, Robert A. Buckle and Viv B. Hall (1995), "Dating New Zealand business cycles", New Zealand Economic Papers, 29, 143-171.King, R.G. and C.I. Plosser (1994), "Real business cycles and the test of the Adelmans", Journal of Monetary Economics, 33, 405-438.

MIAESR (2013), "Phase of Business Cycles, Australia 1960 - 2011”, 10 December 2012, downloaded 18 April 2013 from http://melbourneinstitute.com/macro/reports/bcchronology.html.

Mussa, Michael (2010), "Global economic prospects as of September 30, 2010: A moderating pace of global recovery", presented at the $18^{\text {th }}$ semi-annual meeting on Global Economic Prospects.

NBER Business Cycle Dating Committee (2010), “The NBER's Business Cycle Dating Committee" and "The NBER's Business Cycle Dating Procedure: Frequently asked questions", 20 September, downloaded 22 March 2011 from http://www.nber.org/cycles/recessions.html.

Pagan, Adrian R. (2005), "Some Econometric Analysis of Constructed Binary Time Series", Centre for Applied Macroeconomic Analysis (CAMA) Working Paper 7/2005, May, Australian National University. 
Reddell, Michael and Cath Sleeman (2008), "Some perspectives on past recessions", Reserve Bank of New Zealand Bulletin, 71(2), 5-21.

Reinhart, Carmen M. and Kenneth S. Rogoff ((2009), This time is different: Eight centuries of financial folly, Princeton University Press.

Wynne, Mark A. and Nathan S. Balke (1992), “Are deep recessions followed by strong recoveries?", Economics Letters, 39, 183-189.

Sichel, Daniel E. (1994), "Inventories and the three phases of the business cycle"; Journal of Business and Economic Statistics, 12(3), 269-277. 
New Zealand real GDP, log levels, 1947q2 to 2012q3

Growth Cycle Contraction Phases/Recessions indicated by shading

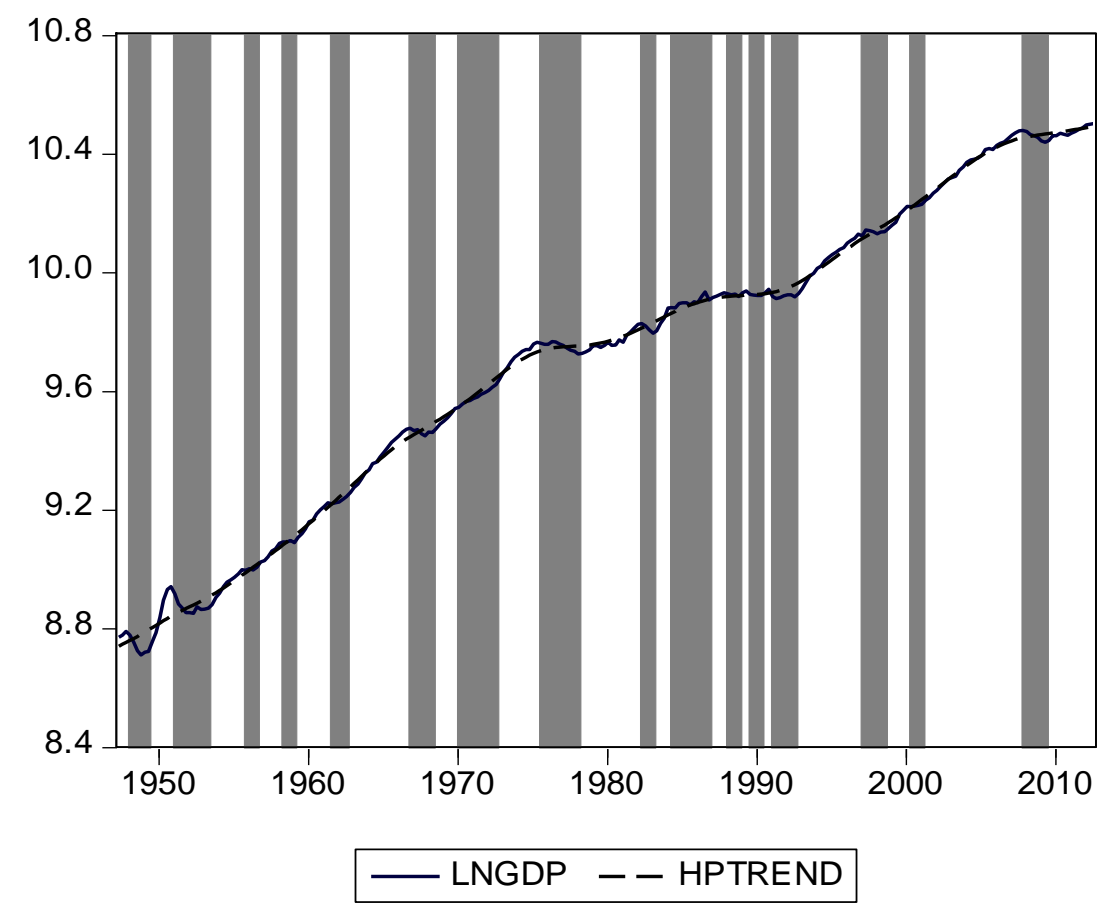

New Zealand Real GDP, log levels, 1947q2 to 2012q3

Classical Business Cycle Contraction Phases/Recessions indicated by shading

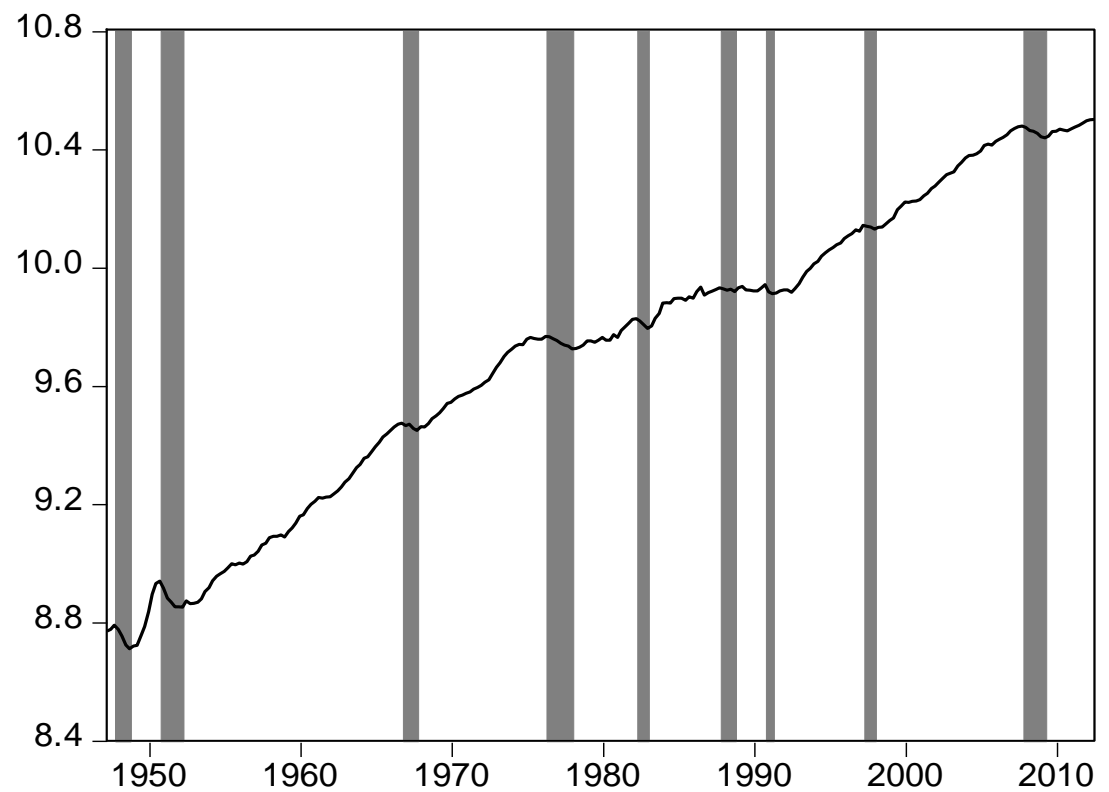

Figure 1. Growth and Classical cycles, New Zealand's real GDP, 1947q2 to 2012q3 
New Zealand Real GDP, log levels, 1956q1 to 2012q3

Classical Business Cycle Contraction Phases/Recessions indicated by shading

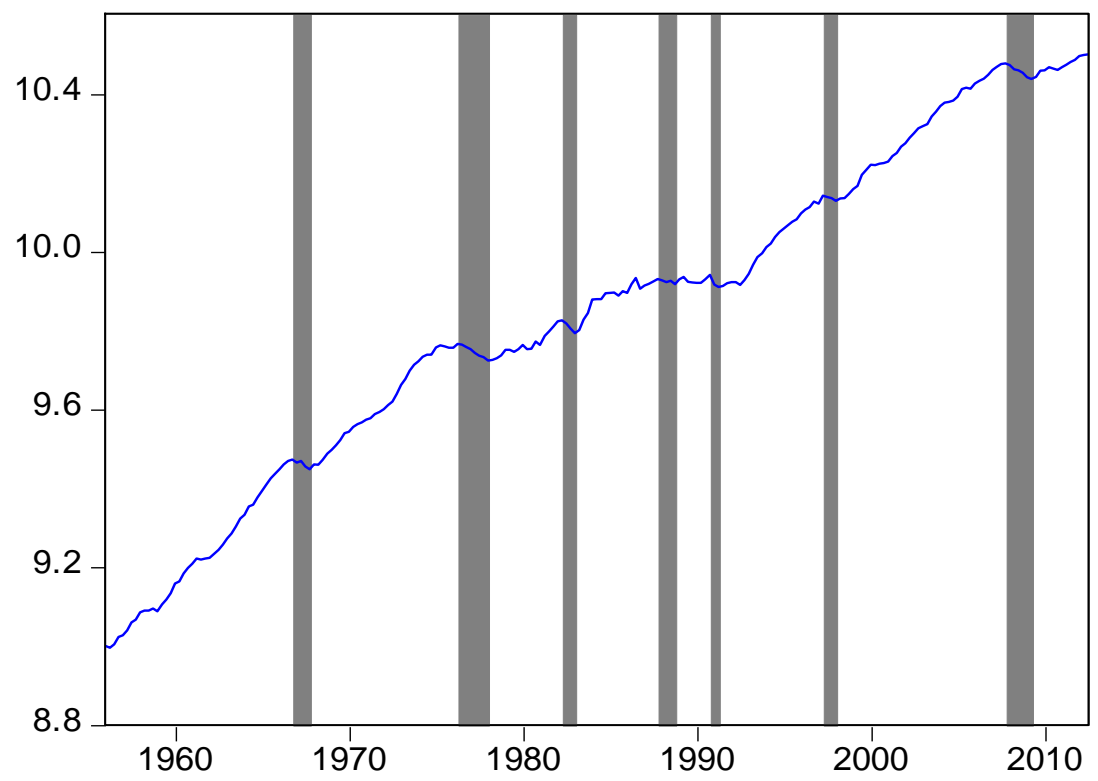

New Zealand Total Employment, log levels, 1956q1 to 2012q3 Classical Employment Contraction Phases/Recessions indicated by shading

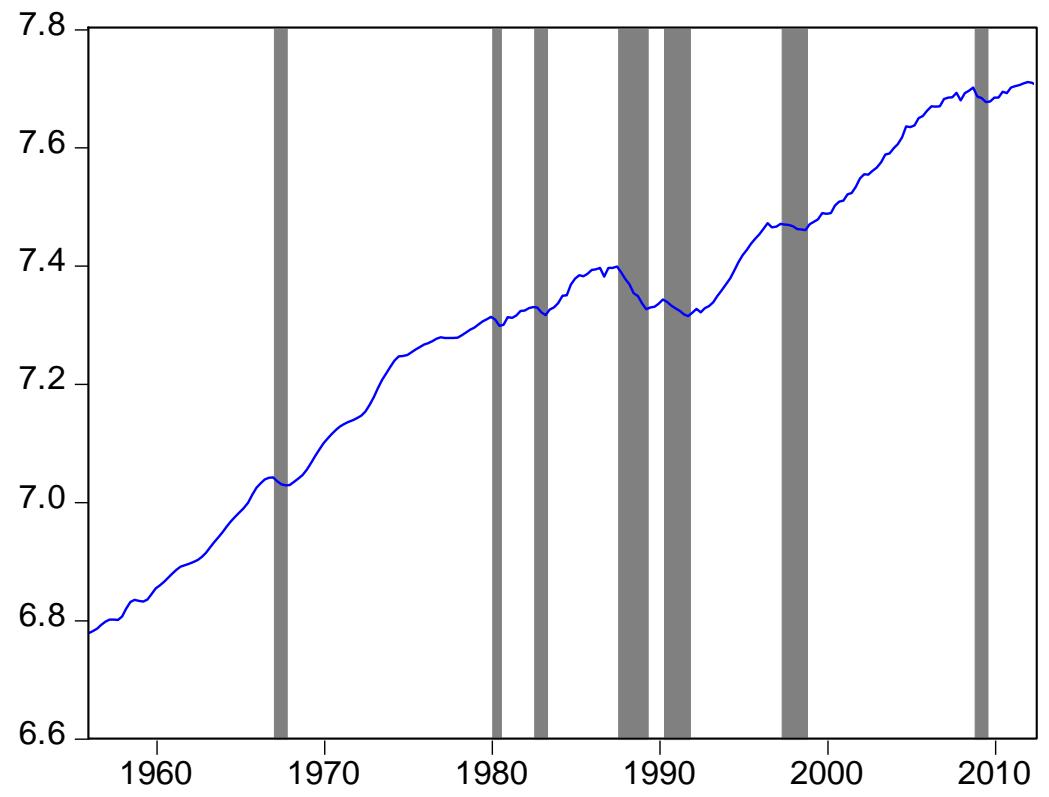

Figure 2. Classical GDP \& Employment Cycles, New Zealand, 1956q1 to 2012q3 


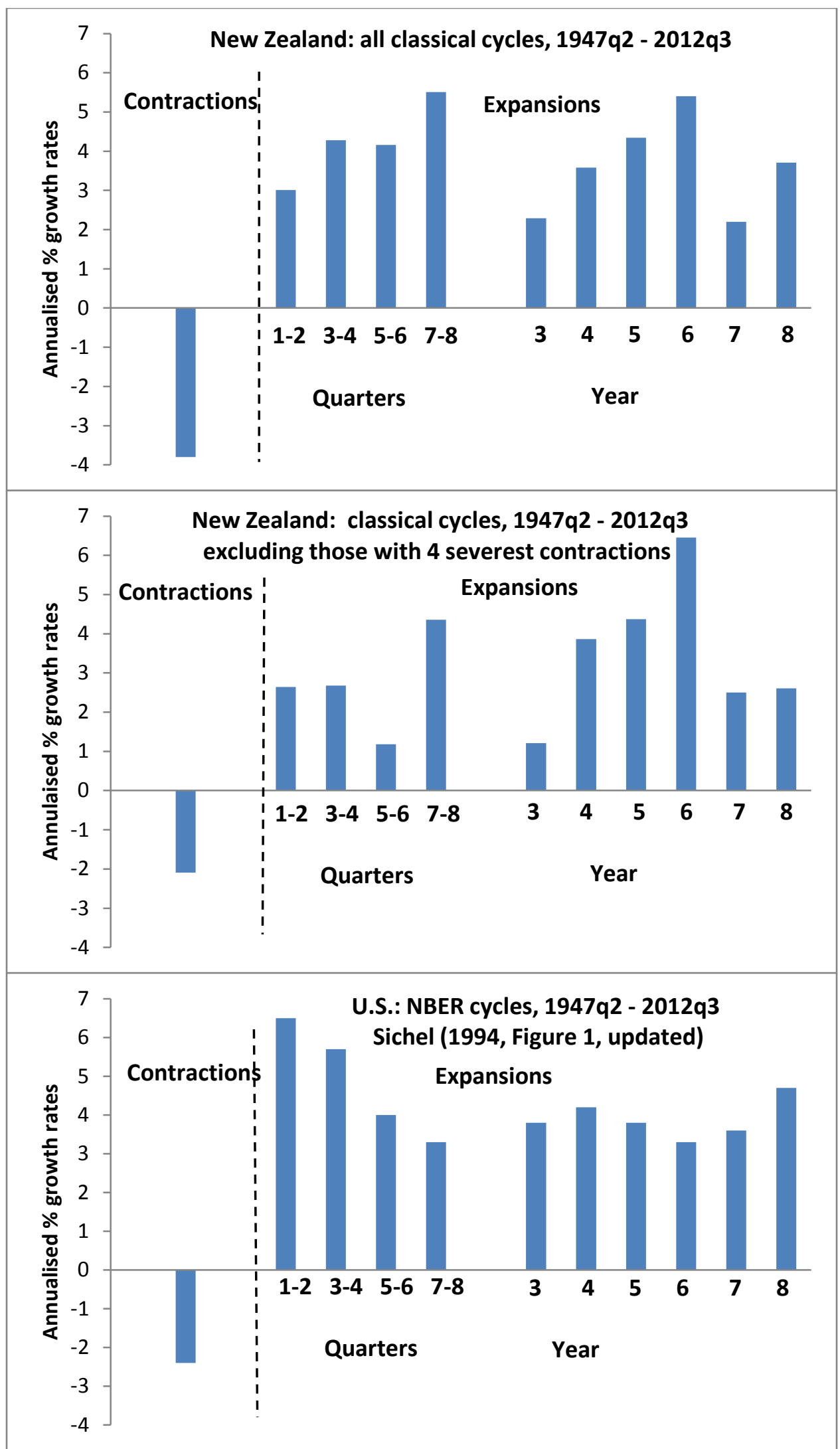

Figure 3. Average growth rates over New Zealand and U.S. real GDP cycles 

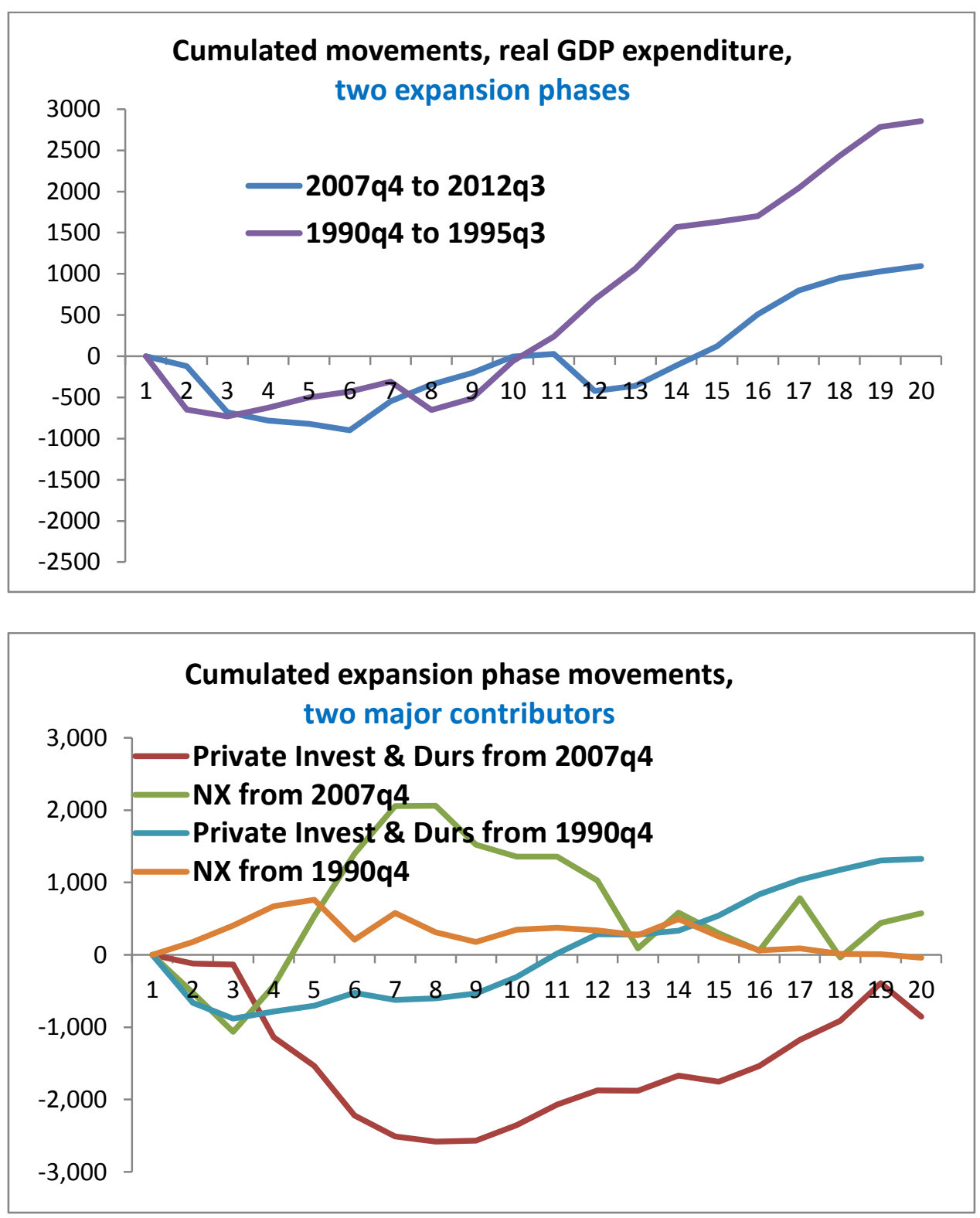

Figure 4. Strength and sustainability of New Zealand's current expansion phase 

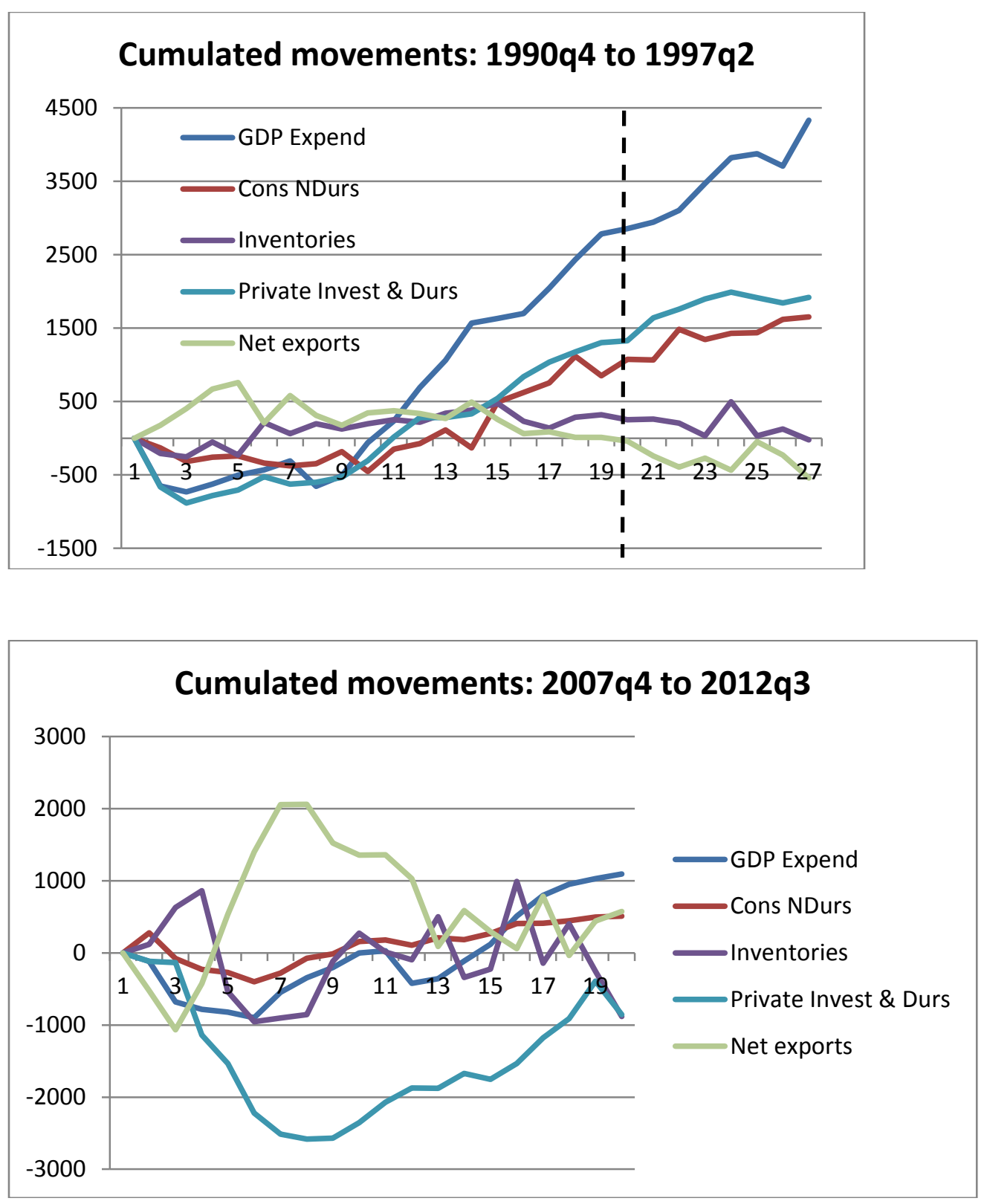

Figure 4 (continued). Strength and sustainability of New Zealand's current expansion phase 

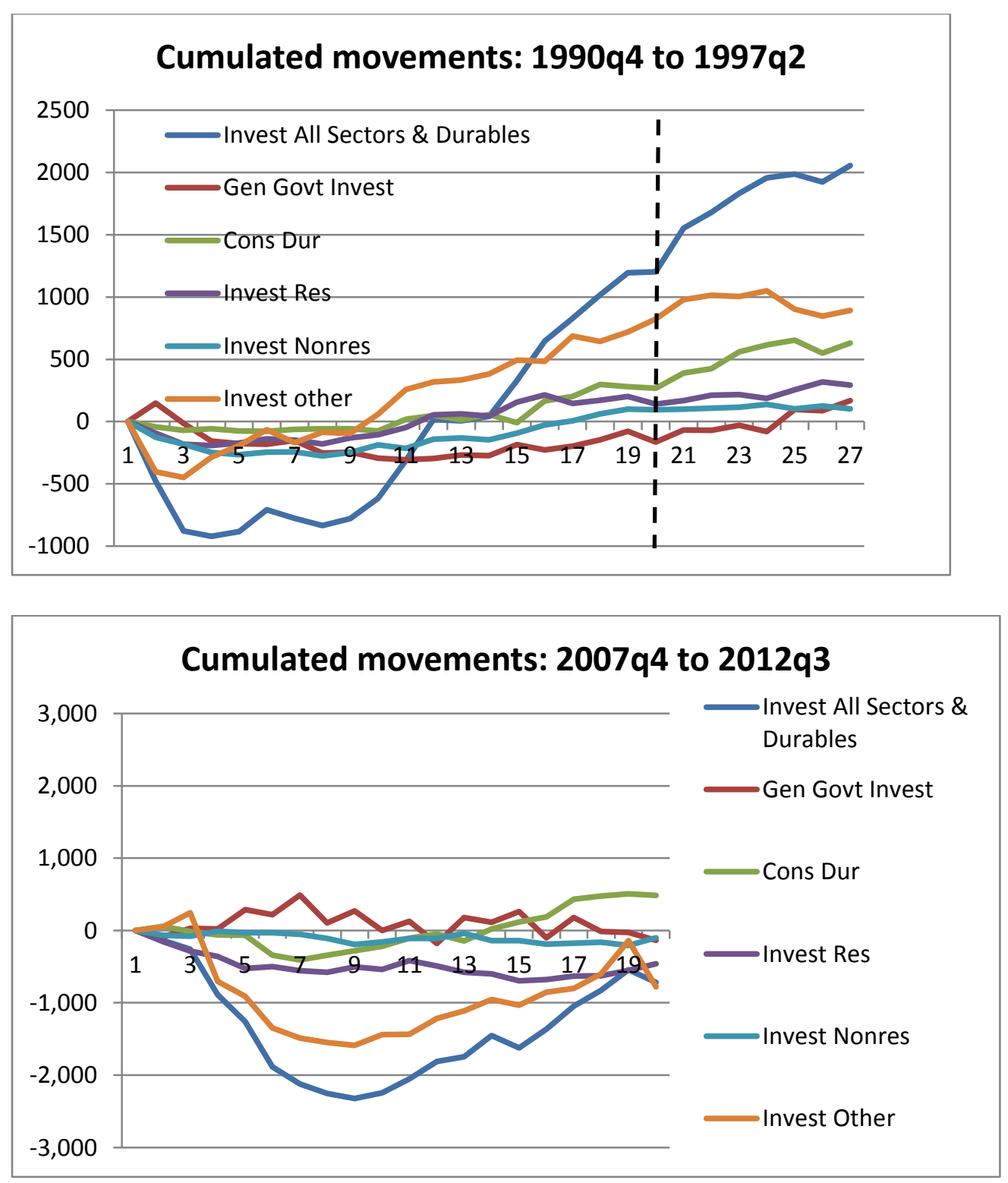

Figure 4 (continued). Strength and sustainability of New Zealand's current expansion phase 
Table 1. New Zealand's Classical Real GDP Business Cycles: 1947 - 2012

Classical Cycles

Dates of peaks and troughs

Duration in quarters

by year and quarter

\begin{tabular}{cccccc}
\hline Peak & Trough & Expansion & Contraction & \multicolumn{3}{c}{ Cycle } \\
\cline { 5 - 6 } & & phase & phase & Peak to peak & Trough to trough \\
\hline 1947 December & 1948 December & & 4 & & \\
1950 December & 1952 June & 8 & 6 & 12 & 14 \\
1966 December & 1967 December & 58 & 4 & 64 & 62 \\
1976 June & 1978 March & 34 & 7 & 38 & 41 \\
1982 June & 1983 March & 17 & 3 & 24 & 20 \\
1987 December & 1988 December & 19 & 4 & 22 & 23 \\
1990 December & 1991 June & 8 & 2 & 12 & 10 \\
1997 June & 1998 March & 24 & 3 & 26 & 27 \\
2007 December & 2009 June & 39 & 6 & 42 & 45 \\
\hline \multicolumn{2}{c}{ Number of cycle phases/cycles } & 8 & 9 & & 8 \\
\multicolumn{2}{c}{ Average duration } & 25.9 & 4.3 & 30.0 & 30.2 \\
\multicolumn{2}{c}{ Standard deviation } & 17.1 & 1.7 & 17.4 & 17.7 \\
\hline \hline
\end{tabular}

\section{Note:}

Real GDP Classical cycle turning points reflect Bry-Boschan (1971) dating of updated Hall-McDermott (2011) series. 
Table 2. New Zealand's Classical Real GDP Business Cycles: 1947 - 2012

\begin{tabular}{|c|c|c|c|c|c|c|c|}
\hline \multicolumn{8}{|c|}{ Cycle characteristics } \\
\hline \multicolumn{2}{|c|}{ Phase dates } & \multicolumn{2}{|c|}{ Duration } & \multicolumn{2}{|c|}{ Amplitude } & \multicolumn{2}{|c|}{$\begin{array}{c}\text { Cumulated } \\
\text { gain/loss }\end{array}$} \\
\hline Expansion & Contraction & $\mathrm{E}$ & $\mathrm{C}$ & $\mathrm{E}$ & $\mathrm{C}$ & $\mathrm{E}$ & $\mathrm{C}$ \\
\hline & $1948 q 1-1948 q 4$ & & 4 & & -8.0 & & -15.6 \\
\hline 1949q1-1950q4 & $1951 q 1-1952 q 2$ & 8 & 6 & 23.0 & -8.9 & 78.9 & -37.2 \\
\hline $1952 q 3-1966 q 4$ & $1967 q 1-1967 q 4$ & 58 & 4 & 62.3 & -2.5 & 1702.9 & -4.3 \\
\hline 1968q1-1976q2 & $1976 q 3-1978 q 1$ & 34 & 7 & 31.8 & -4.2 & 583.2 & -12.8 \\
\hline $1978 q 2-1982 q 2$ & $1982 q 3-1983 q 1$ & 17 & 3 & 10.2 & -3.2 & 68.8 & -4.5 \\
\hline $1983 q 2-1987 q 4$ & $1988 q 1-1988 q 4$ & 19 & 4 & 13.7 & -1.3 & 178.6 & -2.1 \\
\hline 1989q1-1990q4 & 1991q1-1991q2 & 8 & 2 & 2.4 & -3.1 & 7.5 & -4.0 \\
\hline $1991 q 3-1997 q 2$ & 1997q3-1998q1 & 24 & 3 & 23.2 & -1.3 & 256.7 & -1.6 \\
\hline $1998 q 2-2007 q 4$ & $2008 q 1-2009 q 2$ & 39 & 6 & 34.8 & -4.0 & 710.5 & -11.5 \\
\hline Average & & 25.9 & 4.3 & 25.2 & -4.1 & 448.4 & -10.4 \\
\hline Standard deviation & & 17.1 & 1.6 & 18.5 & 2.7 & 566.3 & 11.2 \\
\hline
\end{tabular}

Notes:

E denotes expansion phase; $\mathrm{C}$ is contraction phase; durations are in quarters; amplitudes are percentages; cumulated gains/losses are percentages of GDP in first quarter of the phase, computed as in Pagan (2005, 8-12) 
Table 3. Should two negative quarters of real GDP growth signal a recession?

\begin{tabular}{|c|c|c|c|c|c|c|}
\hline \multirow[t]{3}{*}{ Date } & \multirow{2}{*}{\multicolumn{2}{|c|}{ Two negative quarters }} & \multicolumn{4}{|c|}{ Bry-Boschan turning point sequencing rules } \\
\hline & & & \multicolumn{2}{|c|}{ Classical cycles } & \multicolumn{2}{|c|}{ Growth cycles } \\
\hline & Peak & Trough & Peak & Trough & Peak & Trough \\
\hline $\mathrm{P}$ & $1947 q 4$ & & $1947 \mathrm{q} 4$ & & $1947 \mathrm{q} 4$ & \\
\hline $\mathrm{T}$ & & $1948 \mathrm{q} 4$ & & $1948 \mathrm{q} 4$ & & $1949 q 2$ \\
\hline $\mathrm{P}$ & $1950 \mathrm{q} 4$ & & $1950 \mathrm{q} 4$ & & $1950 \mathrm{q} 4$ & \\
\hline $\mathrm{T}$ & & $1951 q 4$ & & $1952 q 2$ & & $1953 q 2$ \\
\hline $\mathrm{P}$ & & & & & $1955 \mathrm{q} 3$ & \\
\hline $\mathrm{T}$ & & & & & & $1956 \mathrm{q} 3$ \\
\hline $\mathrm{P}$ & & & & & $1958 \mathrm{q} 1$ & \\
\hline $\mathrm{T}$ & & & & & & 1959q1 \\
\hline $\mathrm{P}$ & & & & & 1961q2 & \\
\hline $\mathrm{T}$ & & & & & & $1962 q 3$ \\
\hline $\mathrm{P}$ & $1967 \mathrm{q} 2$ & & $1966 \mathrm{q} 4$ & & 1966q3 & \\
\hline $\mathrm{T}$ & & $1967 \mathrm{q} 4$ & & $1967 \mathrm{q} 4$ & & $1968 \mathrm{q} 2$ \\
\hline$P$ & & & & & $1969 q 4$ & \\
\hline $\mathrm{T}$ & & & & & & 1972q3 \\
\hline $\mathrm{P}$ & $1975 \mathrm{q} 2$ & & & & $1975 q 2$ & \\
\hline $\mathrm{T}$ & & $1975 q 4$ & & & & \\
\hline $\mathrm{P}$ & 1976q2 & & 1976q2 & & & \\
\hline $\mathrm{T}$ & & 1978q1 & & 1978q1 & & 1978q1 \\
\hline $\mathrm{P}$ & $1982 q 2$ & & $1982 q 2$ & & 1982q1 & \\
\hline $\mathrm{T}$ & & 1983q1 & & 1983q1 & & 1983q1 \\
\hline $\mathrm{P}$ & & & & & $1984 q 1$ & \\
\hline $\mathrm{T}$ & & & & & & $1986 q 4$ \\
\hline $\mathrm{P}$ & $1987 q 4$ & & $1987 q 4$ & & $1987 q 4$ & \\
\hline $\mathrm{T}$ & & $1988 \mathrm{q} 2$ & & $1988 \mathrm{q} 4$ & & $1988 \mathrm{q} 4$ \\
\hline $\mathrm{P}$ & $1989 \mathrm{q} 2$ & & & & $1989 q 2$ & \\
\hline $\mathrm{T}$ & & 1990q2 & & & & 1990q2 \\
\hline $\mathrm{P}$ & 1990q4 & & 1990q4 & & 1990q4 & \\
\hline $\mathrm{T}$ & & 1991q2 & & 1991q2 & & $1992 q 3$ \\
\hline $\mathrm{P}$ & $1997 \mathrm{q} 2$ & & $1997 \mathrm{q} 2$ & & $1996 \mathrm{q} 4$ & \\
\hline $\mathrm{T}$ & & 1998q1 & & 1998q1 & & 1998q3 \\
\hline $\begin{array}{l}P \\
T\end{array}$ & & & & & $2000 q 1$ & 200101 \\
\hline $\mathrm{P}$ & $2007 q 4$ & & $2007 \mathrm{q} 4$ & & $2007 q 3$ & \\
\hline $\mathrm{T}$ & & $2009 \mathrm{q} 2$ & & $2009 \mathrm{q} 2$ & & $2009 \mathrm{q} 2$ \\
\hline $\mathrm{P}$ & 2010q2 & & & & & \\
\hline $\mathrm{T}$ & & $2010 \mathrm{q} 4$ & & & & \\
\hline
\end{tabular}


Table 4. New Zealand's Real GDP Business Cycles: 1947 - 2012

\begin{tabular}{|c|c|c|c|c|c|c|c|c|c|c|c|}
\hline \multicolumn{6}{|c|}{ Classical Cycles } & \multicolumn{6}{|c|}{ Growth Cycles } \\
\hline \multicolumn{2}{|c|}{$\begin{array}{c}\text { Dates of peaks } \\
\text { and troughs, } \\
\text { by year and } \\
\text { quarter }\end{array}$} & \multicolumn{4}{|c|}{ Duration in quarters } & \multicolumn{2}{|c|}{$\begin{array}{c}\text { Dates of peaks } \\
\text { and troughs, } \\
\text { by year and } \\
\text { quarter }\end{array}$} & \multicolumn{4}{|c|}{ Duration in quarters } \\
\hline \multirow[t]{2}{*}{$\mathrm{P}$} & \multirow[t]{2}{*}{$\mathrm{T}$} & \multirow{2}{*}{$\begin{array}{l}\text { Exp. } \\
\text { Phase }\end{array}$} & \multirow{2}{*}{$\begin{array}{l}\text { Contr. } \\
\text { Phase }\end{array}$} & \multicolumn{2}{|c|}{ Cycle } & \multirow[t]{2}{*}{$\mathrm{P}$} & \multirow[t]{2}{*}{$\mathrm{T}$} & \multirow{2}{*}{$\begin{array}{l}\text { Exp. } \\
\text { phase }\end{array}$} & \multirow{2}{*}{$\begin{array}{l}\text { Contr. } \\
\text { phase }\end{array}$} & \multicolumn{2}{|c|}{ Cycle } \\
\hline & & & & PTP & TPT & & & & & PTP & TPT \\
\hline $47 q 4$ & $48 \mathrm{q} 4$ & & 4 & & & $47 q 4$ & $49 q 2$ & & 6 & & \\
\hline \multirow[t]{4}{*}{$50 \mathrm{q} 4$} & $52 q 2$ & 8 & 6 & 12 & 14 & $50 \mathrm{q} 4$ & $53 \mathrm{q} 2$ & 6 & 10 & 12 & 16 \\
\hline & & & & & & $55 \mathrm{q} 3$ & $56 \mathrm{q} 3$ & 9 & 4 & 19 & 13 \\
\hline & & & & & & $58 \mathrm{q} 1$ & $59 q 1$ & 6 & 4 & 10 & 10 \\
\hline & & & & & & $61 \mathrm{q} 2$ & $62 \mathrm{q} 3$ & 9 & 5 & 13 & 14 \\
\hline \multirow[t]{2}{*}{$66 q 4$} & $67 q 4$ & 58 & 4 & 64 & 62 & $66 \mathrm{q} 3$ & $68 \mathrm{q} 2$ & 16 & 7 & 21 & 23 \\
\hline & & & & & & $69 q 4$ & $72 q 3$ & 6 & 11 & 13 & 17 \\
\hline $76 q 2$ & $78 q 1$ & 34 & 7 & 38 & 41 & $75 \mathrm{q} 2$ & $78 \mathrm{q} 1$ & 11 & 11 & 22 & 22 \\
\hline \multirow[t]{2}{*}{$82 q 2$} & $83 q 1$ & 17 & 3 & 24 & 20 & $82 \mathrm{q} 1$ & $83 q 1$ & 16 & 4 & 27 & 20 \\
\hline & & & & & & $84 q 1$ & $86 q 4$ & 4 & 11 & 8 & 15 \\
\hline \multirow[t]{2}{*}{$87 q 4$} & $88 \mathrm{q} 4$ & 19 & 4 & 22 & 23 & $87 q 4$ & $88 \mathrm{q} 4$ & 4 & 4 & 15 & 8 \\
\hline & & & & & & $89 q 2$ & $90 \mathrm{q} 2$ & 2 & 4 & 6 & 6 \\
\hline $90 \mathrm{q} 4$ & $91 \mathrm{q} 2$ & 8 & 2 & 12 & 10 & $90 q 4$ & $92 q 3$ & 2 & 7 & 6 & 9 \\
\hline \multirow[t]{2}{*}{$97 q 2$} & $98 \mathrm{q} 1$ & 24 & 3 & 26 & 27 & $96 q 4$ & $98 \mathrm{q} 3$ & 17 & 7 & 24 & 24 \\
\hline & & & & & & $00 q 1$ & 01q1 & 6 & 4 & 13 & 10 \\
\hline $07 q 4$ & $09 q 2$ & 39 & 6 & 42 & 45 & $07 q 3$ & $09 q 2$ & 26 & 7 & 30 & 33 \\
\hline \multicolumn{2}{|c|}{$\begin{array}{l}\text { Number of } \\
\text { cycle phases/ } \\
\text { cycles }\end{array}$} & 8 & 9 & 8 & 8 & $\begin{array}{r}\text { Numbe } \\
\text { cycle } \\
\text { cycle }\end{array}$ & hases/ & 15 & 16 & 15 & 15 \\
\hline \multicolumn{2}{|c|}{$\begin{array}{l}\text { Average } \\
\text { duration }\end{array}$} & 25.9 & 4.3 & 30.0 & 30.2 & $\begin{array}{r}\text { Averag } \\
\text { durat }\end{array}$ & & 9.3 & 6.6 & 15.9 & 16.0 \\
\hline \multicolumn{2}{|c|}{$\begin{array}{l}\text { Standard } \\
\text { deviation }\end{array}$} & 17.1 & 1.7 & 17.4 & 17.7 & $\begin{array}{r}\text { Standar } \\
\text { devis }\end{array}$ & & 6.7 & 2.8 & 7.5 & 7.3 \\
\hline
\end{tabular}

Notes:

Classical cycle turning points reflect Bry-Boschan (1971) dating of updated Hall-McDermott (2011) series.

Growth cycle turning points reflect HP1600 detrending, and Bry-Boschan assisted dating.

$\mathrm{P}=$ Peak; $\mathrm{T}=$ Trough

Exp. $=$ Expansion; Contr. $=$ Contraction; $\mathrm{PTP}=$ Peak to Peak; TPT $=$ Trough to Trough 
Table 5. New Zealand's Classical GDP \& Employment Cycles: 1956 - 2012

\begin{tabular}{|c|c|c|c|c|c|c|c|c|c|c|c|}
\hline \multicolumn{6}{|c|}{ Real GDP Cycles } & \multicolumn{6}{|c|}{ Employment Cycles } \\
\hline \multicolumn{2}{|c|}{$\begin{array}{c}\text { Dates of peaks } \\
\text { and troughs, } \\
\text { by year and } \\
\text { quarter }\end{array}$} & \multicolumn{4}{|c|}{ Duration in quarters } & \multicolumn{2}{|c|}{$\begin{array}{c}\text { Dates of peaks } \\
\text { and troughs, } \\
\text { by year and } \\
\text { quarter }\end{array}$} & \multicolumn{4}{|c|}{ Duration in quarters } \\
\hline \multirow[t]{2}{*}{$\mathrm{P}$} & \multirow[t]{2}{*}{$\mathrm{T}$} & \multirow{2}{*}{$\begin{array}{l}\text { Exp. } \\
\text { Phase }\end{array}$} & \multirow{2}{*}{$\begin{array}{l}\text { Contr. } \\
\text { Phase }\end{array}$} & \multicolumn{2}{|c|}{ Cycle } & \multirow[t]{2}{*}{$\mathrm{P}$} & \multirow[t]{2}{*}{$\mathrm{T}$} & \multirow{2}{*}{$\begin{array}{l}\text { Exp. } \\
\text { phase }\end{array}$} & \multirow{2}{*}{$\begin{array}{l}\text { Contr. } \\
\text { phase }\end{array}$} & \multicolumn{2}{|c|}{ Cycle } \\
\hline & & & & PTP & TPT & & & & & PTP & TPT \\
\hline $66 q 4$ & $67 \mathrm{q} 4$ & & 4 & & & $67 q 1$ & $67 \mathrm{q} 4$ & & 3 & & \\
\hline $76 \mathrm{q} 2$ & $78 \mathrm{q} 1$ & 34 & 7 & 38 & 41 & $80 \mathrm{q} 1$ & $80 \mathrm{q} 3$ & 49 & 2 & 52 & 51 \\
\hline $82 q 2$ & $83 \mathrm{q} 1$ & 17 & 3 & 24 & 20 & $82 \mathrm{q} 3$ & $83 q^{2}$ & 8 & 3 & 10 & 11 \\
\hline $87 \mathrm{q} 4$ & $88 \mathrm{q} 4$ & 19 & 4 & 22 & 23 & $87 \mathrm{q} 3$ & $89 q^{2}$ & 17 & 7 & 20 & 24 \\
\hline $90 \mathrm{q} 4$ & $91 \mathrm{q} 2$ & 8 & 2 & 12 & 10 & $90 \mathrm{q} 2$ & $91 \mathrm{q} 4$ & 4 & 6 & 11 & 10 \\
\hline $97 \mathrm{q}^{2}$ & $98 \mathrm{q} 1$ & 24 & 3 & 26 & 27 & $97 \mathrm{q} 2$ & $98 \mathrm{q} 4$ & 22 & 6 & 28 & 28 \\
\hline $07 \mathrm{q} 4$ & $09 q^{2}$ & 39 & 6 & 42 & 45 & $\begin{array}{l}08 \mathrm{q} 4 \\
12 \mathrm{q} 1\end{array}$ & $09 \mathrm{q} 3$ & $\begin{array}{l}40 \\
10\end{array}$ & 3 & $\begin{array}{l}46 \\
13\end{array}$ & 43 \\
\hline $\begin{array}{r}\text { Numbe } \\
\text { cycl } \\
\text { cycl }\end{array}$ & f & 6 & 7 & 6 & 6 & $\begin{array}{r}\text { Numbe } \\
\text { cycle } \\
\text { cycle }\end{array}$ & $\begin{array}{l}\text { f } \\
\text { hases/ }\end{array}$ & 7 & 7 & 7 & 6 \\
\hline $\begin{array}{r}\text { Averas } \\
\text { dura }\end{array}$ & & 23.5 & 4.1 & 27.3 & 27.7 & $\begin{array}{r}\text { Averag } \\
\text { durat }\end{array}$ & & 21.4 & 4.3 & 25.7 & 27.8 \\
\hline $\begin{array}{r}\text { Standa } \\
\text { devi }\end{array}$ & & 11.4 & 1.8 & 11.0 & 13.2 & $\begin{array}{r}\text { Standar } \\
\text { devia }\end{array}$ & & 17.0 & 2.0 & 17.2 & 16.6 \\
\hline
\end{tabular}

Notes:

Employment cycle turning points reflect Bry-Boschan (1971) dating of linked Simon Chapple (1994)-RBNZ-SNZ

Total Employment series

$\mathrm{P}=$ Peak; $\mathrm{T}=$ Trough

Exp. $=$ Expansion; Contr. $=$ Contraction; $\mathrm{PTP}=$ Peak to Peak; TPT $=$ Trough to Trough 
Table 6. Synchronisation of New Zealand's

Classical real GDP and Employment Cycles: 1956q1 - 2012q3

\begin{tabular}{|c|c|c|c|}
\hline $\begin{array}{l}\text { Employment turning point } \\
\text { lagging/leading } \\
\text { GDP turning point }\end{array}$ & Concordance & GMM test & Correlation \\
\hline \multicolumn{4}{|l|}{ Employment lagging by: } \\
\hline 1 quarter & .8894 & $4.65 * * *$ & .527 \\
\hline 2 quarters & .8711 & $3.88^{* * *}$ & .451 \\
\hline 3 quarters & .8348 & $2.16^{* *}$ & .299 \\
\hline 4 quarters & .7892 & 0.45 & .108 \\
\hline 8 quarters & .7397 & -0.33 & -.085 \\
\hline Contemporaneous & .8722 & $4.13^{* * *}$ & .452 \\
\hline \multicolumn{4}{|l|}{ Employment leading by: } \\
\hline 2 quarters & .8000 & 0.79 & .122 \\
\hline 1 quarter & .8407 & $2.58 * * *$ & .309 \\
\hline
\end{tabular}

Notes:

The GMM test is the $t$-test on the coefficient $\mathrm{C}$ in the implicit equation $\operatorname{demGDP}(\mathrm{t}) * \operatorname{demEmp}(\mathrm{t}+\mathrm{k})-\mathrm{C}=0$, where $\mathrm{k}$ is the number of quarters by which employment lags/leads GDP.

The GMM estimation was conducted using the Bartlett kernel with a fixed bandwidth of 4.The null hypothesis of no concordance between the demeaned binary expansion/contraction phases for the GDP and employment series is rejected for one-tail tests, if the test result is greater than critical values of 2.35 ( 1 per cent level, denoted ***), 1.65 (5 per cent level, denoted $* *)$, and 1.28 (10 per cent level, denoted $*$ ). 
Table 7. Contractions/Recessions, Expansions, Recoveries

New Zealand's Classical real GDP Business Cycles: 1947 - 2012

\begin{tabular}{|c|c|c|c|c|c|}
\hline \multirow{2}{*}{\multicolumn{2}{|c|}{ Contraction/recession Phases }} & \multirow[t]{2}{*}{ Duration (qtrs) } & \multirow[t]{2}{*}{ Amplitude (\%) } & \multicolumn{2}{|c|}{ Amplitude (\%) } \\
\hline & & & & Per qtr & Per annum \\
\hline Peak & Trough & & & & \\
\hline $1947 q 4$ & $1948 \mathrm{q} 4$ & 4 & -7.70 & -1.93 & -7.70 \\
\hline $1950 q 4$ & $1952 q 2$ & 6 & -8.51 & -1.42 & -5.67 \\
\hline $1966 \mathrm{q} 4$ & $1967 q 4$ & 4 & -2.47 & -0.62 & -2.47 \\
\hline 1976q2 & $1978 \mathrm{q} 1$ & 7 & -4.11 & -0.59 & -2.35 \\
\hline $1982 q 2$ & $1983 q 1$ & 3 & -3.19 & -1.06 & -4.26 \\
\hline $1987 q 4$ & $1988 \mathrm{q} 4$ & 4 & -1.29 & -0.32 & -1.29 \\
\hline 1990q4 & $1991 q 2$ & 2 & -3.07 & -1.54 & -6.14 \\
\hline $1997 \mathrm{q} 2$ & $1998 \mathrm{q} 1$ & 3 & -1.30 & -0.43 & -1.74 \\
\hline $2007 q 4$ & $2009 q 2$ & 6 & -3.90 & -0.65 & -2.60 \\
\hline \multicolumn{2}{|c|}{ Mean } & 4.3 & -3.95 & -0.95 & -3.80 \\
\hline \multicolumn{2}{|c|}{ Standard deviation } & 1.7 & & & \\
\hline \multicolumn{2}{|c|}{ Mean (excl. phases $1 \& 2)$} & 4.1 & -2.76 & -0.74 & -2.98 \\
\hline \multicolumn{2}{|c|}{ Mean (excl. phases $1,2 \& 7$ ) } & 4.5 & -2.71 & -0.61 & -2.45 \\
\hline
\end{tabular}

Expansion Phases

\begin{tabular}{|c|c|c|c|c|c|}
\hline Trough & Peak & & & & \\
\hline $1948 \mathrm{q} 4$ & $1950 \mathrm{q} 4$ & 8 & 25.85 & 3.23 & \\
\hline $1952 q 2$ & $1966 q 4$ & 58 & 86.46 & 1.49 & \\
\hline $1967 q 4$ & $1976 q 2$ & 34 & 37.41 & 1.10 & \\
\hline 1978q1 & $1982 q 2$ & 17 & 10.73 & 0.63 & \\
\hline 1983q1 & $1987 q 4$ & 19 & 14.69 & 0.77 & \\
\hline $1988 \mathrm{q} 4$ & $1990 \mathrm{q} 4$ & 8 & 2.44 & 0.30 & \\
\hline $1991 q 2$ & $1997 q 2$ & 24 & 26.11 & 1.09 & \\
\hline 1998q1 & $2007 q 4$ & 39 & 41.68 & 1.07 & \\
\hline \multicolumn{2}{|l|}{ Mean } & 25.9 & 30.67 & 1.21 & 4.84 \\
\hline \multicolumn{2}{|c|}{ Standard deviation } & 17.1 & & & \\
\hline \multicolumn{2}{|c|}{ Mean (excl. phase 1) } & 28.43 & 31.36 & 0.92 & 3.69 \\
\hline
\end{tabular}

Recovery to prior Peak

Trough date

\begin{tabular}{lllll}
\hline $1948 \mathrm{q} 4$ & 5 & 13.45 & 2.69 & 10.76 \\
$1952 \mathrm{q} 2$ & 8 & 9.32 & 1.17 & 4.68 \\
$1967 \mathrm{q} 4$ & 4 & 4.06 & 1.01 & 4.04 \\
$1978 \mathrm{q} 1$ & 13 & 6.49 & 0.50 & 2.00 \\
$1983 \mathrm{q} 1$ & 2 & 3.48 & 1.74 & 6.96 \\
$1988 \mathrm{q} 4$ & 8 & 2.44 & 0.30 & 1.20 \\
$1991 \mathrm{q} 2$ & 7 & 3.47 & 0.50 & 2.00 \\
$1998 \mathrm{q} 1$ & 3 & 1.74 & 0.58 & 2.32 \\
$2009 \mathrm{q} 2$ & 9 & 4.39 & 0.49 & 1.96 \\
\hline Mean & 6.6 & 5.43 & 1.00 & 3.99 \\
Standard deviation & 3.4 & & & \\
Mean (excl. phase 4) & 5.8 & & & \\
Mean (excl. phase 1) & & 4.42 & & \\
\hline \hline
\end{tabular}


Table 8. Growth rates over New Zealand's Classical real GDP Business Cycles

annualised percentage changes

\begin{tabular}{|c|c|c|c|c|c|c|c|c|c|c|c|c|c|c|c|c|}
\hline \multirow[t]{3}{*}{ Peak } & \multirow[t]{3}{*}{ Trough } & \multirow{3}{*}{$\begin{array}{l}\text { Growth rate during } \\
\text { Contractions }\end{array}$} & \multicolumn{14}{|c|}{ Growth rate during Expansions } \\
\hline & & & \multicolumn{4}{|c|}{ Quarters } & \multicolumn{10}{|c|}{ Years } \\
\hline & & & $1-2$ & $3-4$ & $5-6$ & $7-8$ & 1 & 2 & 3 & 4 & 5 & 6 & 7 & 8 & 9 & 10 \\
\hline $1947 q 4$ & $1948 q 4$ & -7.70 & 2.43 & 13.05 & 23.07 & 9.29 & 7.82 & 16.72 & & & & & & & & \\
\hline $1950 \mathrm{q} 4$ & $1952 q 2$ & -5.67 & 2.52 & 0.83 & 7.39 & 7.38 & 1.68 & 7.52 & 4.46 & 1.29 & 4.53 & 5.14 & 1.60 & 5.92 & 6.03 & $1.19 \dagger$ \\
\hline $1966 q 4$ & $1967 q 4$ & -2.47 & 2.35 & 5.70 & 4.19 & 6.37 & 4.06 & 5.35 & 2.79 & 2.62 & 4.73 & 7.60 & 2.62 & 1.79 & & \\
\hline $1976 q 2$ & $1978 q 1$ & -2.35 & 1.28 & 4.27 & -1.02 & 3.41 & 2.79 & 1.18 & 0.01 & 6.21 & & & & & & \\
\hline $1982 q^{2}$ & $1983 q 1$ & -4.26 & 6.95 & 10.56 & 0.08 & 3.34 & 8.94 & 1.71 & -0.01 & 1.82 & & & & & & \\
\hline $1987 \mathrm{q} 4$ & $1988 \mathrm{q} 4$ & -1.29 & 3.76 & -2.70 & -3.34 & 4.19 & 0.50 & 1.93 & & & & & & & & \\
\hline $1990 q 4$ & $1991 q 2$ & -6.14 & 1.97 & 0.65 & 1.02 & 7.77 & 1.31 & 4.42 & 5.53 & 4.77 & 4.11 & 3.57 & & & & \\
\hline $1997 q 2$ & $1998 q 1$ & -1.74 & 1.45 & 4.47 & 7.44 & 5.23 & 2.98 & 6.43 & 0.76 & 4.78 & 4.40 & 5.29 & 2.37 & 3.42 & 3.49 & \\
\hline $2007 q 4$ & $2009 q^{2}$ & -2.60 & 4.38 & 1.65 & -1.35 & 2.61 & 3.04 & 0.62 & 2.49 & $\mathrm{~N} / \mathrm{A}+\dagger$ & & & & & & \\
\hline Mean & & -3.80 & 3.01 & 4.28 & 4.16 & 5.51 & 3.68 & 5.10 & 2.29 & 3.58 & 4.44 & 5.40 & 2.20 & 3.71 & & \\
\hline $\begin{array}{l}\text { Mean } \\
\text { (excl. } \\
1,2,5\end{array}$ & $\begin{array}{l}\text { hases } \\
\text { Q 7) }\end{array}$ & -2.09 & 2.64 & 2.68 & 1.18 & 4.36 & 2.67 & 3.10 & 1.51 & 3.86 & 4.57 & 6.45 & 2.50 & 2.61 & & \\
\hline
\end{tabular}

\section{Notes:}

$\dagger$ For the expansion phase from 1952q2, annualised percentage growth rates for years 11, 12, 13 and 14 are 5.28, 7.13, 5.57, and 5.34.

$\dagger \dagger$ N/A refers to this recovery phase being still incomplete; the production based GDP peak of $\$ 35,400 \mathrm{~m}$ (1995/96 prices) in the December 2007 quarter was regained only in the September 2011 quarter $(\$ 35,574 \mathrm{~m})$. 


\section{Appendix}

Table A1. Quarterly real GDP Estimates, 1947q2 - 2012q3 (seasonally adjusted, 1995-96 prices)

\begin{tabular}{|c|c|c|c|c|}
\hline Year & Mar & Jun & Sep & Dec \\
\hline 1947 & & 6422.26 & 6466.04 & 6553.91 \\
\hline 1948 & 6465.60 & 6323.25 & 6133.74 & 6049.13 \\
\hline 1949 & 6106.78 & 6122.84 & 6329.10 & 6522.43 \\
\hline 1950 & 6862.97 & 7274.69 & 7543.31 & 7612.69 \\
\hline 1951 & 7436.20 & 7183.65 & 7089.85 & 6973.88 \\
\hline 1952 & 6976.18 & 6965.14 & 7113.27 & 7052.89 \\
\hline 1953 & 7060.93 & 7082.10 & 7169.53 & 7343.66 \\
\hline 1954 & 7445.52 & 7614.46 & 7734.19 & 7798.09 \\
\hline 1955 & 7860.41 & 7954.05 & 8066.61 & 8045.63 \\
\hline 1956 & 8091.88 & 8056.48 & 8128.98 & 8279.31 \\
\hline 1957 & 8312.95 & 8421.73 & 8594.68 & 8652.52 \\
\hline 1958 & 8811.84 & 8854.37 & 8854.35 & 8897.84 \\
\hline 1959 & 8836.33 & 8995.78 & 9108.65 & 9254.16 \\
\hline 1960 & 9478.06 & 9527.88 & 9730.91 & 9868.06 \\
\hline 1961 & 9972.69 & 10102.42 & 10075.49 & 10104.96 \\
\hline 1962 & 10124.29 & 10222.49 & 10323.88 & 10465.72 \\
\hline 1963 & 10633.21 & 10762.52 & 10952.73 & 11176.55 \\
\hline 1964 & 11291.42 & 11529.43 & 11581.40 & 11792.27 \\
\hline 1965 & 11980.53 & 12171.46 & 12381.16 & 12519.23 \\
\hline 1966 & 12668.78 & 12821.64 & 12939.68 & 12986.96 \\
\hline 1967 & 12878.42 & 12933.25 & 12753.00 & 12665.75 \\
\hline 1968 & 12829.37 & 12814.65 & 12975.02 & 13179.59 \\
\hline 1969 & 13303.44 & 13455.88 & 13643.51 & 13884.33 \\
\hline 1970 & 13928.69 & 14102.09 & 14207.41 & 14272.01 \\
\hline 1971 & 14362.81 & 14424.95 & 14572.20 & 14646.25 \\
\hline 1972 & 14750.46 & 14906.03 & 15043.43 & 15339.69 \\
\hline 1973 & 15692.55 & 15924.35 & 16260.70 & 16506.10 \\
\hline 1974 & 16665.61 & 16847.52 & 16944.48 & 16939.07 \\
\hline 1975 & 17259.54 & 17352.11 & 17295.13 & 17242.42 \\
\hline 1976 & 17246.10 & 17403.58 & 17385.64 & 17267.03 \\
\hline 1977 & 17179.34 & 17012.02 & 16900.98 & 16842.35 \\
\hline 1978 & 16688.12 & 16716.31 & 16794.99 & 16916.66 \\
\hline 1979 & 17153.52 & 17155.57 & 17065.71 & 17180.07 \\
\hline 1980 & 17356.71 & 17184.16 & 17196.41 & 17510.89 \\
\hline 1981 & 17358.75 & 17771.26 & 17968.32 & 18200.09 \\
\hline 1982 & 18436.98 & 18478.84 & 18334.87 & 18100.03 \\
\hline 1983 & 17888.67 & 18037.75 & 18510.49 & 18822.93 \\
\hline 1984 & 19487.63 & 19511.11 & 19495.80 & 19789.86 \\
\hline 1985 & 19821.51 & 19824.57 & 19682.65 & 19904.21 \\
\hline
\end{tabular}


Table A1. Quarterly real GDP Estimates, 1947q2 - 2012q3 (cont.) (seasonally adjusted, 1995-96 prices)

\begin{tabular}{ccccc}
\hline \hline Year & Mar & Jun & Sep & Dec \\
\hline \hline 1986 & 19820.49 & 20256.47 & 20570.96 & 20019.59 \\
1987 & 20180.92 & 20282.00 & 20405.00 & 20516.00 \\
1988 & 20450.00 & 20366.00 & 20427.00 & 20251.00 \\
1989 & 20513.00 & 20632.00 & 20389.00 & 20353.00 \\
1990 & 20319.00 & 20319.00 & 20511.00 & 20745.00 \\
1991 & 20244.00 & 20108.00 & 20172.00 & 20306.00 \\
1992 & 20368.00 & 20372.00 & 20219.00 & 20476.00 \\
1993 & 20806.00 & 21272.00 & 21700.00 & 21911.00 \\
1994 & 22257.00 & 22448.00 & 22832.00 & 23108.00 \\
1995 & 23326.00 & 23519.00 & 23728.00 & 23873.00 \\
1996 & 24239.00 & 24485.00 & 24639.00 & 24982.00 \\
1997 & 24858.00 & 25358.00 & 25277.00 & 25209.00 \\
1998 & 25028.00 & 25168.00 & 25209.00 & 25464.00 \\
1999 & 25773.00 & 25994.00 & 26732.00 & 27061.00 \\
2000 & 27431.00 & 27404.00 & 27489.00 & 27541.00 \\
2001 & 27640.00 & 28028.00 & 28257.00 & 28703.00 \\
2002 & 28961.00 & 29378.00 & 29711.00 & 30082.00 \\
2003 & 30235.00 & 30388.00 & 30993.00 & 31366.00 \\
2004 & 31833.00 & 32094.00 & 32154.00 & 32279.00 \\
2005 & 32589.00 & 33223.00 & 33357.00 & 33250.00 \\
2006 & 33703.00 & 33943.00 & 34106.00 & 34446.00 \\
2007 & 34880.00 & 35164.00 & 35401.00 & 35460.00 \\
2008 & 35320.00 & 34951.00 & 34843.00 & 34623.00 \\
2009 & 34225.00 & 34077.00 & 34270.00 & 34824.00 \\
2010 & 34842.00 & 35112.00 & 34994.00 & 34875.00 \\
2011 & 35129.00 & 35330.00 & 35574.00 & 35791.00 \\
2012 & 36118.00 & 36211.00 & 36282.00 & \\
\hline \hline
\end{tabular}


Table A2. Quarterly Total Employment, 1956q1 - 2012q3

(HLFS-consistent, seasonally adjusted, 000)

\begin{tabular}{lrrrr}
\hline \hline Year & Mar & Jun & Sep & Dec \\
\hline \hline 1956 & 877.45 & 880.20 & 883.95 & 889.72 \\
1957 & 894.64 & 897.53 & 897.49 & 897.06 \\
1958 & 902.25 & 914.83 & 925.11 & 928.37 \\
1959 & 926.73 & 925.23 & 928.66 & 937.71 \\
1960 & 946.16 & 951.58 & 957.04 & 963.82 \\
1961 & 970.47 & 976.87 & 981.77 & 984.12 \\
1962 & 986.67 & 989.38 & 993.01 & 998.54 \\
1963 & 1005.46 & 1014.86 & 1023.93 & 1032.24 \\
1964 & 1041.06 & 1051.01 & 1060.24 & 1068.27 \\
1965 & 1076.40 & 1083.89 & 1093.91 & 1108.97 \\
1966 & 1122.09 & 1130.65 & 1137.50 & 1141.43 \\
1967 & 1142.05 & 1134.60 & 1128.77 & 1126.29 \\
1968 & 1127.22 & 1132.85 & 1139.31 & 1146.81 \\
1969 & 1156.82 & 1169.83 & 1183.30 & 1196.73 \\
1970 & 1209.26 & 1219.04 & 1228.52 & 1237.27 \\
1971 & 1244.74 & 1249.74 & 1254.14 & 1257.75 \\
1972 & 1262.36 & 1267.78 & 1276.44 & 1290.81 \\
1973 & 1307.33 & 1327.38 & 1346.35 & 1361.67 \\
1974 & 1376.62 & 1391.22 & 1401.40 & 1402.12 \\
1975 & 1404.88 & 1410.91 & 1417.59 & 1423.85 \\
1976 & 1429.29 & 1432.57 & 1437.61 & 1443.81 \\
1977 & 1447.00 & 1445.85 & 1445.74 & 1445.71 \\
1978 & 1446.43 & 1452.47 & 1459.25 & 1446.04 \\
1979 & 1471.66 & 1479.18 & 1486.94 & 1492.33 \\
1980 & 1498.12 & 1491.41 & 1475.62 & 1478.04 \\
1981 & 1497.03 & 1495.78 & 1501.88 & 1513.43 \\
1982 & 1514.37 & 1520.41 & 1523.31 & 1522.08 \\
1983 & 1510.12 & 1502.87 & 1517.00 & 1522.33 \\
1984 & 1532.56 & 1553.23 & 1553.69 & 1582.20 \\
1985 & 1598.48 & 1607.23 & 1604.77 & 1611.50 \\
1986 & 1622.18 & 1624.09 & 1627.36 & 1603.93 \\
1987 & 1627.59 & 1627.24 & 1631.01 & 1615.51 \\
1988 & 1597.00 & 1582.73 & 1559.52 & 1552.08 \\
1989 & 1533.42 & 1517.78 & 1522.06 & 1524.05 \\
1990 & 1532.50 & 1543.25 & 1536.71 & 1526.86 \\
1991 & 1519.34 & 1513.07 & 1504.47 & 1500.26 \\
1992 & 1509.08 & 1518.52 & 1509.93 & 1520.38 \\
1993 & 1526.08 & 1536.00 & 1551.53 & 1568.00 \\
1994 & 1583.43 & 1599.55 & 1620.96 & 1643.66 \\
1995 & 1662.89 & 1677.85 & 1695.47 & 1709.65 \\
\hline \hline & & & & \\
\hline
\end{tabular}


Table A2. Quarterly Total Employment, 1956q1 - 2012q3 (cont.) (HLFS-consistent, seasonally adjusted, 000)

\begin{tabular}{lllll}
\hline \hline Year & Mar & Jun & Sep & Dec \\
\hline \hline 1996 & 1722.99 & 1738.98 & 1755.47 & 1743.58 \\
1997 & 1745.61 & 1753.42 & 1751.67 & 1750.30 \\
1998 & 1746.32 & 1738.52 & 1737.43 & 1734.77 \\
1999 & 1752.92 & 1759.67 & 1767.13 & 1785.32 \\
2000 & 1783.68 & 1785.63 & 1808.68 & 1821.05 \\
2001 & 1823.49 & 1842.85 & 1847.62 & 1866.92 \\
2002 & 1893.73 & 1906.93 & 1906.05 & 1918.41 \\
2003 & 1928.74 & 1945.94 & 1971.40 & 1975.19 \\
2004 & 1992.55 & 2006.98 & 2028.96 & 2067.51 \\
2005 & 2064.76 & 2071.64 & 2097.52 & 2104.29 \\
2006 & 2123.07 & 2139.76 & 2137.55 & 2138.88 \\
2007 & 2166.28 & 2170.84 & 2171.62 & 2188.95 \\
2008 & 2160.52 & 2187.71 & 2196.05 & 2208.88 \\
2009 & 2174.96 & 2170.12 & 2155.07 & 2157.24 \\
2010 & 2171.05 & 2170.75 & 2192.82 & 2187.05 \\
2011 & 2208.84 & 2213.46 & 2217.26 & 2223.19 \\
2012 & 2228.56 & 2226.18 & 2217.81 & \\
\hline \hline
\end{tabular}




\section{Notes}

${ }^{i}$ Our quarterly turning points, which we refer to as BB turning points, come from a RATS program written by Dr Kunhong Kim. The initial version of the program was written to replicate successfully Bry and Boschan monthly results, and was then adapted to reflect what King and Plosser (1994, p 410, 411) have described as: (i) the Bry and Boschan general procedure of looking for turning points in a smoothed seasonally adjusted series "... so as not to be misled by 'erratic' movements."; and (ii) BB's handling of quarterly data in a way similar to that of Burns and Mitchell (1946) “. .. by simply setting each month of the quarter equal to the quarterly value and proceeding to set the series as monthly." Harding and Pagan (2002, p 368, fn 4) have similarly characterised the smoothing aspect as " ... simply aiding in the process of identifying peaks and troughs through the removal of some idiosyncratic variation.", but then went on to suggest that the benefit of smoothing could be 'much reduced' if dating were being done with quarterly data. This led them to write their now-widely used BBQ program, which ignores the smoothing element of the monthly BB program (Harding and Pagan, 2002, pp 368-69). For our quarterly New Zealand real GDP data, we find that for almost all episodes the $\mathrm{BB}$ and $\mathrm{BBQ}$ programs produce identical results. There are two exceptions: (i) BB calls a four-quarter recession from a 1987q4 peak, as against BBQ producing a nine-quarter recession from a peak of 1986q3; and (ii) BB does not call the short two-quarter recession from a 2010q2 peak, whereas BBQ does. In both cases, the difference can be attributed to the absence or presence of the smoothing element. New Zealand introduced a previously announced GST of ten per cent from 1 October 1986, and the resulting two-quarter upward spike in real GDP for 1986q2 and 1986q3 was followed by a major downward spike in 1986q4. We have classified the quarters directly affected by the introduction of the ten per cent GST as 'erratic' movements rather as quarters of recession. Inspection of recently revised SNZ data for 2010 suggests that any short two-quarter recession from the 2010q2 peak called by BBQ but not by BB is a relatively marginal call, directly related to excluding or retaining the smoothing element. On balance, therefore, the methodological approach adopted in this paper has been to present our preferred turning points as coming from the BB program (which includes BB's smoothing element), and to make transparent as above the two periods where the BB and BBQ programs produce different results.

ii Utilising the BBQ method, Hall and McDermott (2009, Table 1) included in their 'benchmark' turning points a peak at $1958 \mathrm{q} 2$ and a trough at $1959 \mathrm{q} 1$. This reflected the BBQ program not including a smoothing element. The BB program used in this paper includes the smoothing element, and so leads to what was a very marginal call of a 3-quarter 1958-59 contraction by the BBQ method not being called by the BB method.

iii Neither the BB nor BBQ methods picked these 1975 and 1989/90 technical recessions, though as stated in footnote $i$ above the BBQ method did call 2010q3 and 2010q4 as a two-quarter recession.

iv Chapple's HLFS-consistent series were published as de-seasonalised, but our graphing of his employment series showed that there still remained a very significant seasonal pattern. Accordingly, the results we present reflect our having run the employment series through Eviews' X13 program. See Figure 2, bottom panel, and Appendix Table A2 for the resulting X13 seasonally adjusted linked total employment series.

${ }^{v}$ On the relatively unusual nature of these two cycles, and the cautionary comments on our real GDP series observations prior to 1954, see Hall and McDermott (2011, section 6)

${ }^{\text {vi }}$ For an assessment of relative timing of 64 time series, including total employment, with respect to a deviation reference chronology over the period 1947-74, see Haywood and Campbell (1976).

${ }^{v i i}$ Hall (2011, pp 431-432) defines slumps broadly as "extended periods of low resource utilisation", and identified them specifically as periods when " ... the employed fraction of the labor aged 25 through $54 \ldots$ was less than its normal level of 95.5 per cent of the labor force." Thus, it would last from when employment falls below its normal level during a contraction phase and continue through to when employment regained its normal level during an expansion phase.

viii Wynne and Balke (1992) also assessed whether the length of recession had affected the strength of recovery, and concluded that recession length had not significantly affected the strength of recovery.

ix This opposite average two-year recovery pattern for the U.S. for the updated period has been maintained, despite the recovery from its most recent 2009 trough having been atypically slow (see, for example, Dominguez and Shapiro (2013), DS). DS have attributed this slowness primarily to successive financial shocks from Europe during 2010, 2012, and especially 2011. 